\title{
Synthetic approaches to phomactins: Novel oxidation of homoallylic alcohols using tetra- $\mathbf{n}$-propylammonium perruthenate \\ DOI:
}

10.1016/j.tet.2018.05.068

\section{Document Version}

Accepted author manuscript

Link to publication record in Manchester Research Explorer

Citation for published version (APA):

Blackburn, T. J., \& Thomas, E. J. (2018). Synthetic approaches to phomactins: Novel oxidation of homoallylic alcohols using tetra- $\mathrm{n}$-propylammonium perruthenate. Tetrahedron. https://doi.org/10.1016/j.tet.2018.05.068

\section{Published in:}

Tetrahedron

\section{Citing this paper}

Please note that where the full-text provided on Manchester Research Explorer is the Author Accepted Manuscript or Proof version this may differ from the final Published version. If citing, it is advised that you check and use the publisher's definitive version.

\section{General rights}

Copyright and moral rights for the publications made accessible in the Research Explorer are retained by the authors and/or other copyright owners and it is a condition of accessing publications that users recognise and abide by the legal requirements associated with these rights.

\section{Takedown policy}

If you believe that this document breaches copyright please refer to the University of Manchester's Takedown Procedures [http://man.ac.uk/04Y6Bo] or contact uml.scholarlycommunications@manchester.ac.uk providing relevant details, so we can investigate your claim.

\section{OPEN ACCESS}




\section{Graphical Abstract}

To create your abstract, type over the instructions in the template box below.

Fonts or abstract dimensions should not be changed or altered.

Synthetic approaches to phomactins: novel

Leave this area blank for abstract info.

oxidation of homoallylic alcohols using tetran-propylammonium perruthenate

Timothy J. Blackburn and Eric J. Thomas

The School of Chemistry, The University of Manchester, Manchester, M13 9PL, UK
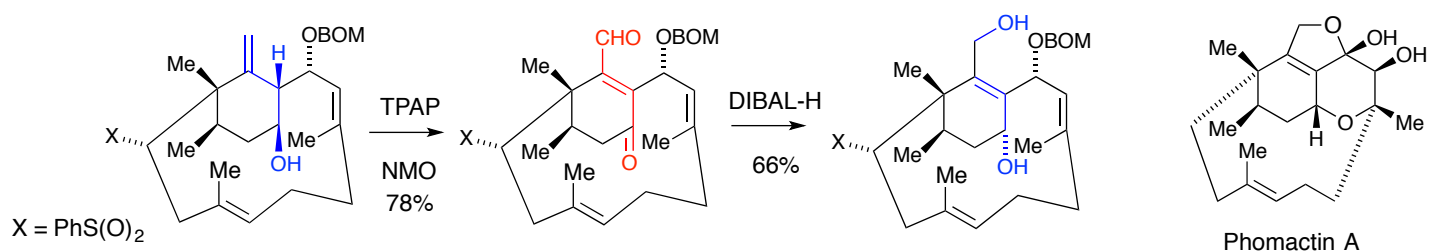

Phomactin A 


\title{
Synthetic approaches to phomactins: novel oxidation of homoallylic alcohols using tetra- $n$-propylammonium perruthenate
}

\author{
Timothy J. Blackburn ${ }^{\mathrm{a}}$ and Eric J. Thomas ${ }^{\mathrm{a}}{ }^{*}$ \\ ${ }^{a}$ The School of Chemistry, The University of Manchester, Manchester, M13 9PL, UK
}

\section{ARTICLE INFO}

Article history:

Received

Received in revised form

Accepted

Available online

\section{Keywords:}

Keyword_1 natural products

Keyword 2 total synthesis

Keyword_3 oxidation

Keyword 4 tetra- $n$-propylammonium perruthenate

Keyword_5 regioselective epoxidation

\section{ABSTRACT}

Previous studies of a synthesis of phomactin A had resulted in the synthesis of a 15methylenebicyclo[9.3.1]pentadecadiene. The next step in the synthesis was to be the epoxidation of this methylenecyclohexane that was hoped would lead to a 1-(hydroxymethyl)cyclohexene by rearrangement of the exocyclic epoxide, but the epoxidation was difficult to carry out regioselectively on advanced intermediates. However, oxidation of a 15-methylenebicyclo[9.3.1]pentadeca-3,7-dien14 -ol using tetra- $n$-propylammonium perruthenate and $N$-methylmorpholine- $N$-oxide led to conversion of this homoallylic alcohol into the corresponding 14-oxobicyclo[9.3.1]pentadeca-1(15),3,7-triene-15carboxaldehyde in one step. Reduction of this using DIBAL-H gave a promising intermediate for a synthesis of a phomactin. The scope of this oxidation of homoallylic alcohols was briefly investigated. 2009 Elsevier Ltd. All rights reserved.

\section{Introduction}

The phomactins are a novel group of diterpenes originally isolated from the marine fungus Phoma sp. although other sources have since been identified. They are characterised by a bicyclo[9.3.1]pentadecenyl skeleton as exemplified by phomactins A, D, G and B2, 1 - 4, see Figure 1, and show interesting biological activity including platelet activating factor antagonism. ${ }^{1,2}$ They are recognised as challenging targets for synthesis with many synthetic approaches and six total syntheses reported to date. ${ }^{3,4}$ Phomactin A $\mathbf{1}$, in particular, has been the focus of many synthetic studies with three total syntheses now complete.
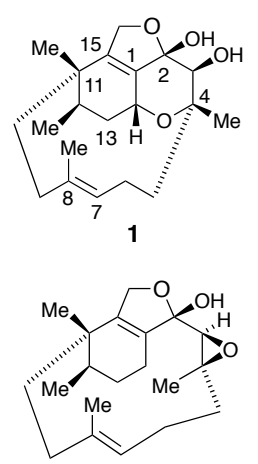

3
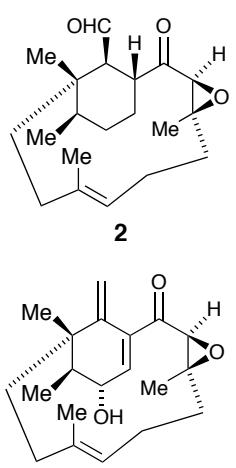

4
Figure 1 Structures of representative phomactins showing the numbering scheme used.
In our approach to phomactins, the cyclohexenylmethanol $\mathbf{5}$ was converted stereoselectively into the methylenecyclohexanol 6 using the Still variant of the 2,3-Wittig rearrangement. Development of the side chain using a ytterbium(III) triflate promoted vinyllithium addition to the corresponding aldehyde gave the alcohol 7. Protection of this alcohol as its benzyloxymethyl ether, conversion of the tert-butyldimethylsilyl ether into the corresponding allylic bromide, and base mediated cyclisation, gave the macrocyclic sulphone $\mathbf{8}^{5,6}$ This has the bicyclo[9.3.1]pentadecadienyl structure found in the phomactins and would appear to be a useful advanced intermediate for their synthesis, see Figure 2.

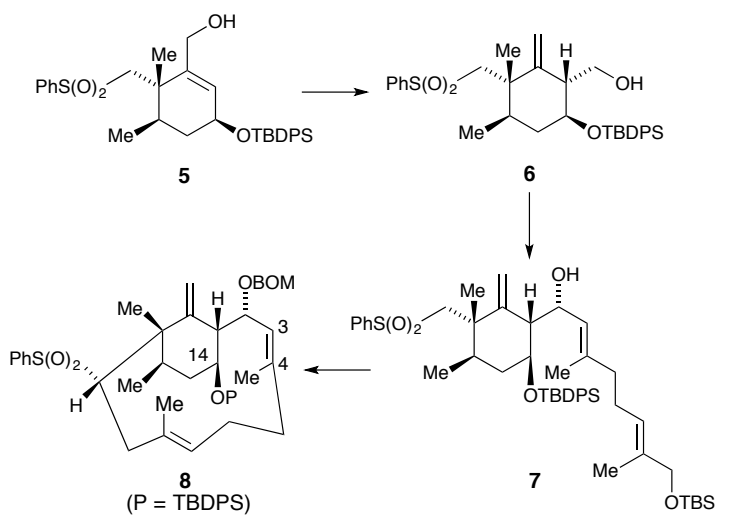

Figure 2 Synthesis of the bicyclo[9.3.1]pentadecenyl sulfone $\mathbf{8}$.

* Corresponding author. Tel.: +44 161275 4613; e-mail: e.j.thomas@manchester.ac.uk 
A possible synthetic route from the sulfone 8 to phomactin A 1 is outlined in Figure 3. Reductive deprotection of the BOMprotected hydroxysulfone $\mathbf{8}$ with concomittant loss of the sulfonyl moiety would give the alcohol 9. Regioselective epoxidation directed by the alcohol at $\mathrm{C} 2$ should then deliver the bis-epoxide 10 possibly as a mixture of isomers. ${ }^{2 a}$ Oxidation of the alcohol would lead to the ketone $\mathbf{1 1}$ but this should be unstable with respect to isomerisation of the $\beta \gamma$-epoxide to the corresponding allylic alcohol that would be expected to equilibrate with the hemi-acetal $\mathbf{1 2}$ by analogy with the behaviour of phomactins A $\mathbf{1}$ and G 3. Removal of the remaining silyl protecting group, inversion of configuration at $\mathrm{C} 14$, and intramolecular opening of the epoxide by the $\mathrm{C} 14$ alcohol, ${ }^{2 \mathrm{~b}}$ would then provide phomactin A 1 . We now describe studies of the early stages of this scheme together with an unexpected oxidation of homoallylic alcohols using tetra- $n$-propylammonium perruthenate.

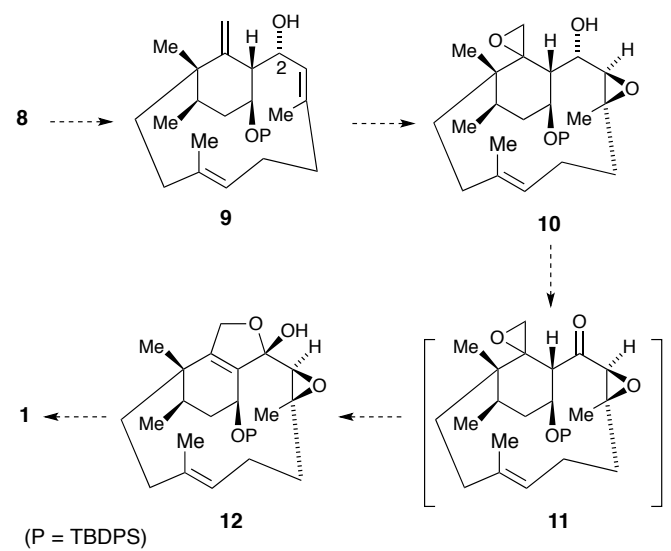

Figure 3 Proposed development of a synthetic approach to phomactin A 1 from the macrocyclic sulfone 8 .

\section{Results and discussion}

\subsection{Epoxidation of a 2-hydroxy-15-methylene- bicyclo[9.3.1]pentadeca-3,7-diene and precursors}

To avoid competing reduction of the benzene rings in the tertbutyldiphenylsilyl ether, the macrocycle $\mathbf{8}$ was first desilylated using tetra- $n$-butylammonium fluoride to give the alcohol $\mathbf{1 3}$ that was converted into the diol $\mathbf{1 4}$ using Birch conditions. Epoxidation of this dihydroxytriene using a small excess of tertbutyl hydroperoxide and $\mathrm{VO}(\mathrm{acac})_{2}$ gave a good yield of a monoepoxide derived from the 3,4-alkene. This was identified as the stereoisomer $\mathbf{1 5}$ by analogy with previous work $^{8}$ and was consistent with a directed epoxidation on the more accessible face of the 3,4-double-bond as indicated by the X-ray crystal structure of the macrocyclic sulfone $\mathbf{8}^{5}$ However, attempts to prepare the bis-epoxide 16 using prolonged reaction times, an excess of the oxidant, or by using $\mathrm{Ti}\left({ }^{i} \mathrm{PrO}\right)_{4}$ or $\mathrm{Mo}(\mathrm{CO})_{6}$ as the catalyst, ${ }^{9}$ were unsuccessful. Lower yields of the monoepoxide 15 were formed in these reactions with none of the required bisepoxide 16 being obtained, Scheme 1. It would appear that the exocyclic double-bond is too hindered in this system, perhaps by the 11-methyl group, for epoxidation to take place.

Epoxidation of the methylenecyclohexane moiety of earlier intermediates in the synthesis was considered as a way round this problem since for these compounds the exocyclic double-bond should be more accessible. Indeed epoxidation of the 2,3-Wittig

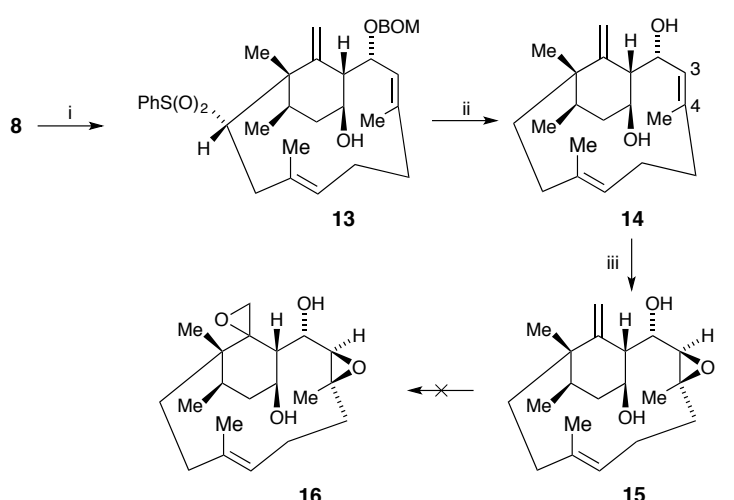

Scheme 1 Epoxidation of the hydroxytriene 14 Reagents and conditions i, TBAF, THF, rt, 16 h (95\%); ii, Na, EtOH, $\mathrm{NH}_{3}$, THF, 45 min (75\%); iii, TBHP, VO(acac) 2 (cat.), benzene, rt, 30 $\min (85 \%)$.

product 6 using either tert-butyl hydroperoxide and $\mathrm{VO}(\mathrm{acac})_{2}$ or $m$-chloroperoxybenzoic acid gave the hydroxyepoxide $\mathbf{1 7}$ as mixtures of diastereoisomers, ratio $c a$. $60: 40$ in both cases, albeit the major isomer from the tert-butyl hydroperoxide oxidation was the minor isomer from the per-acid epoxidation. These hydroxyepoxides were not easy to separate but after oxidation, the diastereoisomeric epoxyaldehydes 18 and 19 could be separated, Scheme 2. The tert-butyl hydroperoxide epoxidation should be directed by the homoallylic alcohol ${ }^{9}$ and would be expected to give epoxyaldehyde $\mathbf{1 8}$ as the major product after oxidation. Approach of the peracid to the less hindered face of the alkene would give isomer 19 after oxidation. These assignments were consistent with ${ }^{1} \mathrm{H}$ NMR data and were confirmed by an X-ray crystal structure of the epoxyaldehyde $\mathbf{1 8}$,

However, preliminary studies of the addition of the vinyllithium reagent derived from the vinylic iodide 20 to the separated epoxyaldehydes $\mathbf{1 8}$ and $\mathbf{1 9}$ gave mixtures of products. These were not properly characterised but, interestingly, side products that involved epoxide cleavage did not appear to predominate. However, the low stereoselectivity of epoxidation of the methylenecyclohexane $\mathbf{6}$ and the formation of mixtures of products from reactions of the aldehydes 18 and 19 with the vinyllithium reagent led to this study being discontinued in favour of studies of epoxidation of hydroxytriene 7 .

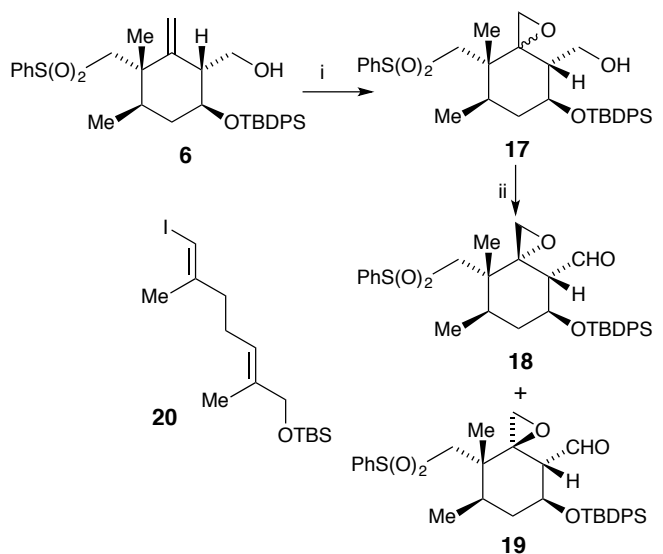

Scheme 2 Epoxidation of methylenecyclohexane 6 Reagents and conditions i, either (a) TBHP, $\mathrm{VO}(\mathrm{acac})_{2}$, benzene, rt, $9 \mathrm{~h}(95 \%$, ratio $60: 40)$ or (b) $m \mathrm{CPBA}, \mathrm{DCM}, \mathrm{rt}, 3 \mathrm{~h}(85 \%$, ratio $40: 60)$; ii, 17 from TBHP epoxidation, py. $\mathrm{SO}_{3},{ }^{i} \mathrm{Pr}_{2} \mathrm{NEt}$, DMSO, DCM, 0 ${ }^{\circ} \mathrm{C}, 15 \min (\mathbf{1 8}, 40 \% ; \mathbf{1 9}, 25 \%)$. 


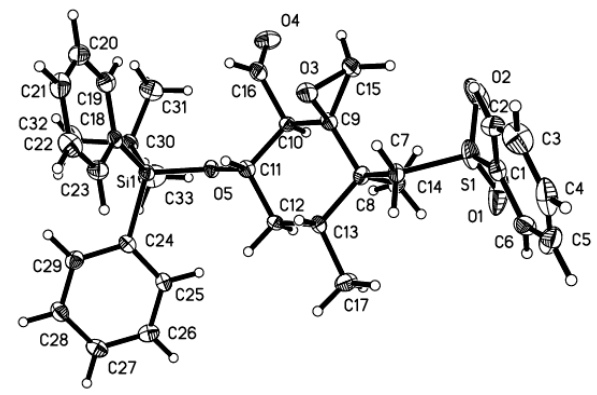

Figure 4 X-Ray crystal structure of epoxyaldehyde 18

The products obtained from epoxidation of the hydroxytriene 7 varied significantly depending on the reaction conditions. Using tert-butyl hydroperoxide and $\mathrm{VO}(\mathrm{acac})_{2}$ at room temperature, the monoepoxide $\mathbf{2 1}$ was obtained regioselectively as a 10:1 mixture of diastereoisomers, the threo-configuration being assigned to the major diastereoisomer $\mathbf{2 1}$ by analogy with the literature. ${ }^{10}$ Initial studies using $m$-chloroperoxybenzoic acid gave the bis-epoxide $\mathbf{2 2}$ as a mixture of diastereoisomers, as well as the monoepoxide 21. However, the use of tert-butyl hydroperoxide and $\mathrm{VO}(\mathrm{acac})_{2}$ under microwave conditions ${ }^{11}$ gave the bis-epoxide $\mathbf{2 3}$, predominantly as one diastereoisomer, in which the methylenecyclohexane had been epoxidised as well as the 2,3-double-bond of the side-chain, Scheme 3.

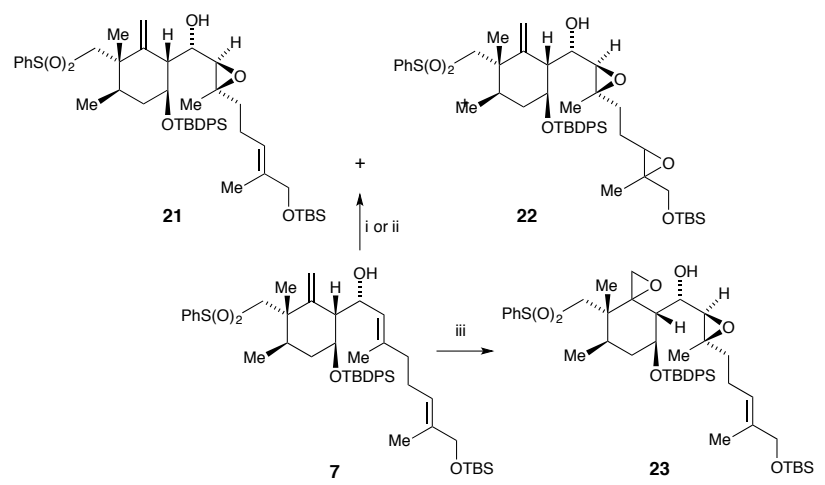

Scheme 3 Epoxidation of the hydroxytriene 7 Reagents and conditions i, TBHP, $\mathrm{VO}(\mathrm{acac})_{2}$, benzene, rt, $10 \mathrm{~min}(\mathbf{2 1}, 78 \%)$; ii, $m$ CPBA, DCM, rt, 1.5 h (21, 15\%, 22, 48\%); iii, TBHP, $\mathrm{VO}(\mathrm{acac})_{2}$, DCM, $60{ }^{\circ} \mathrm{C}$ microwave, $1 \mathrm{~h}(57 \%)$.

The formation of the bis-epoxide $\mathbf{2 3}$ from the microwave promoted epoxidation of the hydroxytriene 7 using tert-butyl hydroperoxide and $\mathrm{VO}(\mathrm{acac})_{2}$ was encouraging and so the epoxidation of the macrocyclic dihydroxytriene 14 was examined under these more forcing conditions. However the major product was a 9:1 mixture of isomers of the bis-epoxide $\mathbf{2 4}$ in which the 7,8-double-bond had been epoxidised rather than the doublebond of the methylenecyclohexane, see Scheme 4.
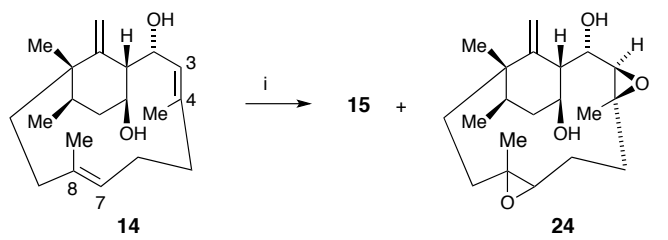

Scheme 4 Epoxidation of the dihydroxytriene 14 under forcing conditions Reagents and conditions i, TBHP, $\mathrm{VO}(\mathrm{acac})_{2}, \mathrm{DCM}$, $60{ }^{\circ} \mathrm{C}$ microwave, $30 \mathrm{~min}(\mathbf{1 5}, 13 \% ; \mathbf{2 4}, 31 \%)$.
Although these investigations into the epoxidation of 2hydroxybicyclopentadecatrienes could have been continued, it was decided instead to look at a second aspect of the proposed synthesis of phomactin A 1, namely the introduction of the C14 alcohol with the required configuration. Indeed alcohol 25 should be available by inverting the configuration of its epimer 13 . Following reductive desulfonylation and BOM-deprotection, epoxidation directed by the hydroxyl group at $\mathrm{C} 2$ would then give the epoxide 26. This should be unstable with respect to isomerisation to the tetrahydropyran $\mathbf{2 7},{ }^{8}$ a promising intermediate for a synthesis of phomactin A 1, see Figure 5.

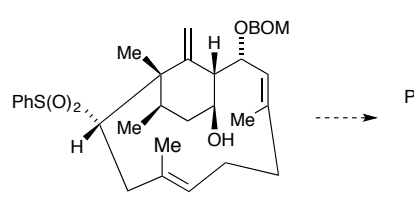

13

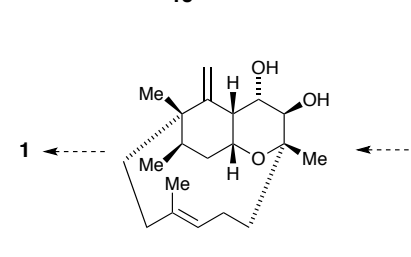

27

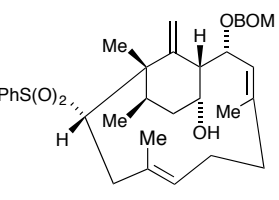

25

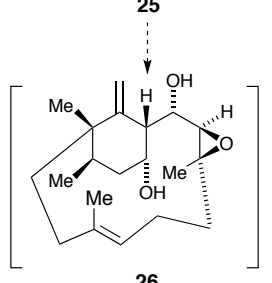

Figure 5 Proposed epoxidation of an inverted C14 alcohol

\subsection{Oxidation of 14-alcohols using tetra-n-propylammonium perruthenate}

Oxidation of the dihydroxyepoxide $\mathbf{1 5}$ was investigated first. In the event, Parikh-Doering conditions using the pyridine. $\mathrm{SO}_{3}$ complex in dimethyl sulfoxide ${ }^{12}$ did not give the expected diketone. Instead the major product was the dienone $\mathbf{2 8}$ identified from spectroscopic data. The geometry of the newly introduced double-bond was not confirmed, see Scheme 5.

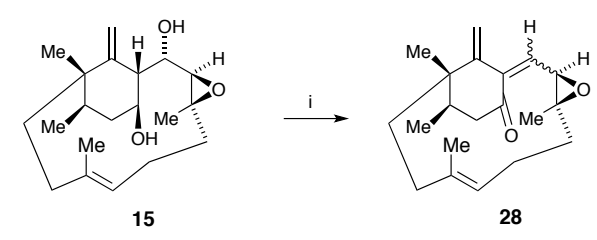

Scheme 5 Oxidation of dihydroxyepoxide 15 Reagents and conditions i, ${ }^{i} \mathrm{Pr}_{2} \mathrm{NEt}$, py. $\mathrm{SO}_{3}$, DCM, DMSO, $-7{ }^{\circ} \mathrm{C}, 5 \min (50 \%)$.

Attempted oxidation of the conjugated diene $\mathbf{2 8}$ using singlet oxygen $\left(\mathrm{O}_{2} \text {, Rose Bengal }\right)^{13}$ gave a mixture of products and reduction using several reagents was similarly inconclusive. Oxidation of the hydroxytriene $\mathbf{1 3}$ was therefore investigated since reduction of the resulting ketone away from the macrocyclic ring was expected to give the required inverted alcohol 25, see Scheme 6. Oxidation of the alcohol 13 using pyridine. $\mathrm{SO}_{3}$-DMSO gave unchanged starting material, the Dess Martin periodinane, pyridinium dichromate and pyridinium chlorochromate gave complex mixtures of products, and a Swern oxidation returned the starting material. However, oxidation using tetra- $n$-propylammonium perruthenate and $N$ methylmorpholine $N$-oxide ${ }^{14}$ gave a single product isolated in a $78 \%$ yield and identified as the keto-aldehyde 29, Scheme 6. 


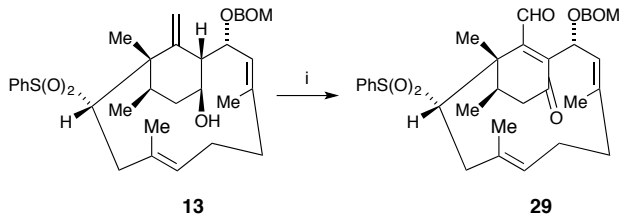

Scheme 6 Oxidation of the hydroxytriene 13 using TPAP Reagents and conditions i, TPAP (cat.), NMO, $4 \AA$ sieves, DCM, rt, 1 h $(78 \%)$,

This oxidation of alcohol $\mathbf{1 3}$ has achieved several of the transformations needed for a synthesis of phomactin A 1. Apart from the intended oxidation of the alcohol at C14, the doublebond migration and exocyclic carbon oxidation were the conversions it had been hoped to carry out by the elusive epoxidation of the methylenecyclohexane and isomerisation of the resulting epoxide. The only similar TPAP oxidations in the literature are the oxidations of derivatives of cholesterol $\mathbf{3 0}$ that give the enediones 31. ${ }^{15}$ However, good yields were only obtained for these reactions if they were promoted using ultrasound, see Figure 6.

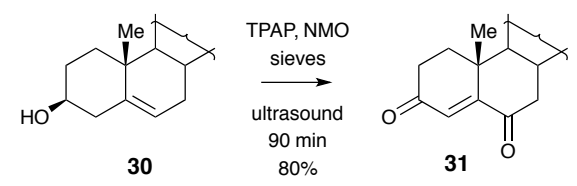

Figure 6 Ultrasound promoted oxidation of cholesterol using TPAP-NMO.

In our hands the efficient conversion of cholesterol $\mathbf{3 0}$ into the enedione 31 did not need ultrasound but was relatively slow (70\% after $24 \mathrm{~h}$ ). The oxidation of simpler homoallylic alcohols using TPAP-NMO was also very briefly investigated, Scheme 7. 3-Methylenecyclohexanol $\mathbf{3 2}^{16}$ gave 3-formylcyclohex-2-enone $33,{ }^{17} 54 \%$, but only after $48 \mathrm{~h}$. Oxidation of the open-chain homoallylic alcohols 34a-c gave mixtures of the non-conjugated ketones 35, together with the conjugated ketones 36 (for 24a,b) and the ketoaldehydes $\mathbf{3 7}$, when the reactions were carried out until no starting materials remained $(8-94 \mathrm{~h})$.
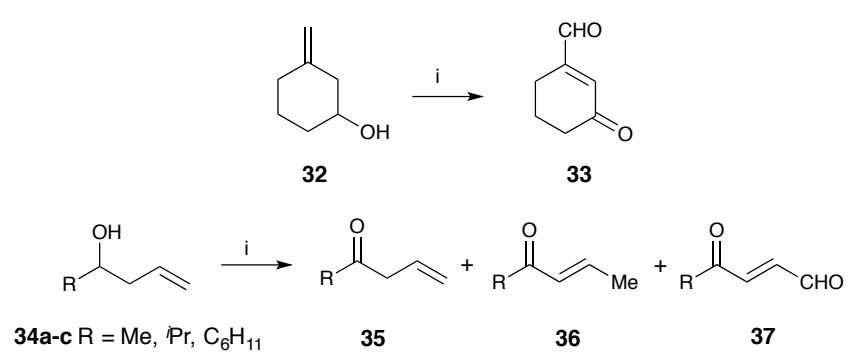

Scheme 7 TPAP-NMO oxidation of simple homoallylic alcohols Reagents and conditions i, TPAP, NMO, $4 \AA$ sieves, DCM, rt (33, 48 h, 54\%; 35a, 36a, 37a, 8 h, 74\%, 10\%, 16\%; 35b, 36b, 37b, 24 h, 47\%, 15\%, 38\%; 35c, 36c, 37c, 94 h, 63\%, 0\%, 26\%).

The oxidation of homoallylic alcohols to unsaturated ketoaldehydes using TPAP-NMO would seem to have some generality albeit better yields were obtained in our hands for the methylenecyclohexanols $\mathbf{1 3}$ and 32. The mechanism of this reaction was not studied, but in the case of a 3methylenecyclohexanol may involve the conversion of the initially formed non-conjugated ketone $\mathbf{3 8}$ into an enolate $\mathbf{3 9}$ that could be susceptible to further oxidation by ruthenium(VII) possibly via an intermediate $\mathbf{4 0}$ with final fragmentation to the ketoaldehyde 33, ${ }^{18}$ see Figure 7.

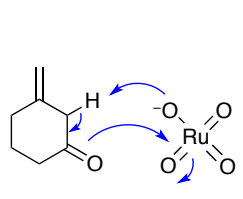

38

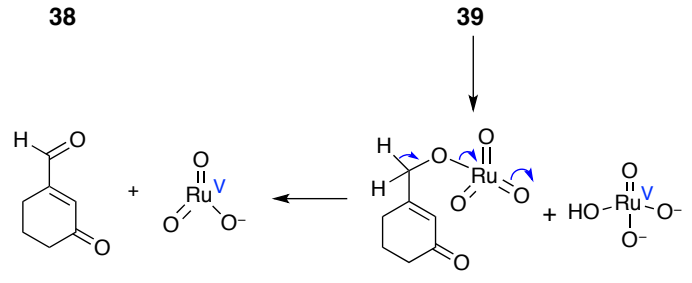

33

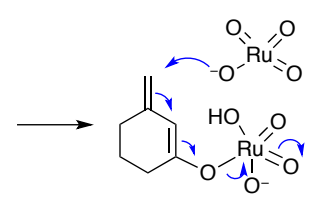

39

40
Figure 7 A rationalization of the TPAP-NMO oxidation of homoallylic alcohols.

To progress a synthesis of phomactin A $\mathbf{1}$, the reduction of the ketoaldehyde 29 was investigated. A Luche reduction converted the aldehyde to the corresponding primary alcohol but only in a low yield. However, reduction with di-isobutylaluminium hydride was more efficient and gave the diol $\mathbf{4 1}$ that now has the required configuration at $\mathrm{C} 14$, in an acceptable yield of $66 \%$. The configuration of the diol $\mathbf{4 1}$ at $\mathrm{C} 14$ was initially assigned on the basis that the hydride would approach the ketone on its less hindered face away from the phenylsulfonyl substituted macrocyclic ring. This assignment was supported by a significant nOe observed between the 12-methyl group and $\mathrm{H}-14$ that suggested that the 14-hydroxyl group was on the opposite side of the six-membered ring from the 12-methyl group, Scheme $8 .{ }^{19}$

Deprotection of the BOM-protected dihydroxysulphone $\mathbf{4 1}$ followed by hydroxyl directed epoxidation would appear to be a useful way forward for a synthesis of phomactin A. However in his synthesis, Pattenden found that in some cases this epoxidation was accompanied by competing epoxidation of the tetrasubstituted 1,15 -alkene. ${ }^{8}$ Although by judicious choice of reaction conditions and substrate this side-reaction could be minimised, in our case, the 3,4-epoxide $\mathbf{1 5}$ had already been prepared and so its oxidation using TPAP-NMO was investigated. A single major product was isolated from this reaction but was identified as the ketolactone $\mathbf{4 2}$ not the expected ketoaldehyde, see Scheme 8. It would appear that the initially formed ketoaldehyde had suffered further oxidation, possibly of the hemiacetal derived from the 2-hydroxyl group and exocyclic aldehyde. ${ }^{14 a, 20}$ Preliminary attempts to reduce this lactone led to mixtures of products that were not identified. To avoid formation of this lactone, the 2-hydroxyl group of the dihydroxyepoxide $\mathbf{1 5}$ would have to be protected before the TPAP-NMO oxidation is carried out. This work was more difficult than expected because will be reported in full elsewhere.

\section{Summary and conclusions}

This paper reports work on the later stages of a proposed synthesis of phomactin A 1. Studies of the epoxidation of 2hydroxy-15-methylenebicyclo[9.3.1]pentadeca-3,7-dienes confirmed the regio- and stereo-selective introduction of the 3,4epoxide, but epoxidation of the exocyclic methylene group at $\mathrm{C} 15$ was only possible on earlier intermediates and gave rise to the formation of mixtures of stereoisomers during attempts to 


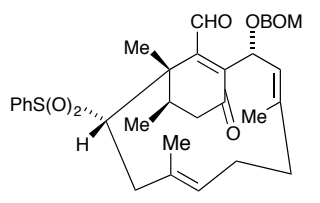

29

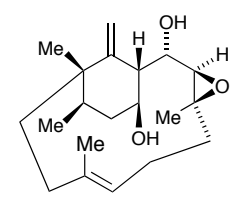

15

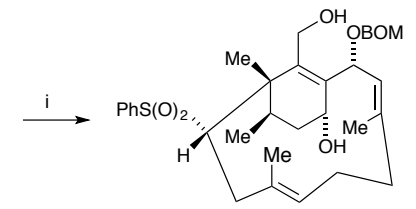

41

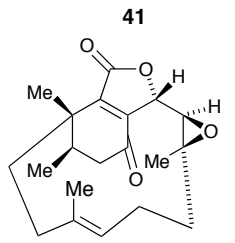

42
Scheme 8 Further modification of advanced intermediates Reagents and conditions i, DIBAL-H, DCM, $-78{ }^{\circ} \mathrm{C}, 1 \mathrm{~h}(66 \%)$; ii, TPAP (cat.), NMO, $4 \AA$ sieves, DCM, rt, 1 h (48\%).

progress the synthesis. However, the oxidation of a 14-hydroxy15-methylenebicyclo[9.3.1]pentadeca-3,7-diene using TPAPNMO was very useful and gave a 14oxobicyclo[9.3.1]pentadeca-1(15),3,7-triene-15-carboxaldehyde, a promising intermediate for the completion of the synthesis. The scope of this novel TPAP-NMO oxidation of homoallylic alcohols was briefly examined and found to be more useful for 3methylenecyclohexanols than for open chain substrates. I

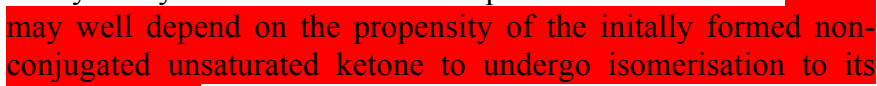

although further work is required if the full potential of this reaction is to be realised.

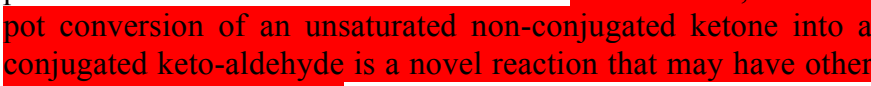

In the next phase of our work on the synthesis of phomactins, the TPAP-NMO oxidation was applied to other macrocyclic epoxides to avoid formation of lactones analogous to the ketolactone $\mathbf{4 2} .^{21}$

\section{Experimental}

\subsection{General experimental details}

Flash column chromatography was performed using Merck silica gel $60 \mathrm{H}$. Light petroleum refers to the fraction boiling between 40 and $60{ }^{\circ} \mathrm{C}$ and was redistilled before use. Tetrahydrofuran was dried over sodium-benzophenone and distilled under nitrogen prior to use. Dichloromethane was dried over $\mathrm{CaH}_{2}$ and distilled before use. Ether refers to diethyl ether. Reactions under non-aqueous conditions were carried out under an atmosphere of nitrogen or argon.

Mass spectra used electron impact ionisation $\left(\mathrm{EI}^{+}\right)$, chemical ionisation using ammonia $\left(\mathrm{CI}^{+}\right)$or electrospray ionisation in the positive or negative modes $\left(\mathrm{ES}^{+}, \mathrm{ES}^{-}\right)$. Low and high resolution mass spectra were recorded using Micromass Trio 200 and Kratos Concept IS spectrometers, respectively. Infra-red spectra were measured using a Genesis FTIR spectrometer on $\mathrm{NaBr}$ plates, either neat or as evaporated films. Nuclear magnetic resonance spectra were recorded using Bruker Ultrashield 500 $(500 \mathrm{MHz})$ and Varian INOVA $400(400 \mathrm{MHz})$ spectrometers. Coupling constants $(J)$ are given in Hertz $(\mathrm{Hz})$ and chemical shifts are relative to tetramethylsilane. Residual non-deuteriated solvent was used as the internal standard.

\subsection{Experimental procedures}

4.2.1 (1SR, 2RS, 10SR, 11SR, 12RS, 14SR, 3E, 7E)-10Benzenesulfonyl-2-benzyloxymethoxy-4,8,11,12-tetramethyl-15methylenebicyclo[9.3.1]pentadeca-3,7-dien-14-ol (13). Tetra- $n$ butylammonium fluoride in THF (1 M, $16.6 \mathrm{~mL}, 16.6 \mathrm{mmol})$ was added to the tert-butyldiphenylsilyl ether $8(0.67 \mathrm{~g}, 0.83 \mathrm{mmol})$ in THF $(5.43 \mathrm{~mL})$ at $\mathrm{rt}$ and the solution stirred at $\mathrm{rt}$ for $16 \mathrm{~h}$. Water $(13 \mathrm{~mL})$ was added and the aqueous phase extracted with ethyl acetate $(4 \times 50 \mathrm{~mL})$. The organic extracts were washed with brine $(100 \mathrm{~mL})$, dried $\left(\mathrm{Na}_{2} \mathrm{SO}_{4}\right)$ and concentrated under reduced pressure. Chromatography of the residue (20:80 to 50:50 ether:light petroleum) gave the title compound $\mathbf{1 3}$ as a white foam $(0.45 \mathrm{~g}, 95 \%), R_{f}=0.13$ (50:50 ether:light petroleum); $v_{\max } / \mathrm{cm}^{-1} 3513,3063,3030,2932,1662,1620,1448,1383,1301$, $1268,1143,1024,925,736$ and $697 ; \delta_{\mathrm{H}}\left(500 \mathrm{MHz}, \mathrm{CDCl}_{3}\right) 7.71-$ $7.74(2 \mathrm{H}, \mathrm{m}, \mathrm{ArH}), 7.19-7.46(8 \mathrm{H}, \mathrm{m}, \mathrm{ArH}), 5.95$ and 5.06 (each $1 \mathrm{H}, \mathrm{d}, J 1.9,15-\mathrm{CH}), 4.98(1 \mathrm{H}, \mathrm{dd}, J 10.1,2.2,2-\mathrm{H}), 4.81(1 \mathrm{H}, \mathrm{d}$, $J 10.1,3-\mathrm{H}$ ), 4.63 and 4.62 (each $1 \mathrm{H}, \mathrm{d}, J 6.6$, OHCHO), 4.57 and 4.47 (each 1H, d, $J$ 11.7, $\mathrm{PhHCH}), 4.13(1 \mathrm{H}, \mathrm{m}, 7-\mathrm{H}), 3.54$ $(1 \mathrm{H}, \mathrm{m}, 14-\mathrm{H}), 3.25(1 \mathrm{H}, \mathrm{m}, 10-\mathrm{H}), 3.11(1 \mathrm{H}, \mathrm{dt}, J 14.8,8.8,13-$ H), $3.01(1 \mathrm{H}, \mathrm{dq}, J 14.8,7.3,12-\mathrm{H}), 2.72(1 \mathrm{H}, \mathrm{dd}, J 12.5,2.2$, $1-$ H), 2.30-2.38 (2H, m, 9- $\left.\mathrm{H}_{2}\right), 1.73-1.90\left(3 \mathrm{H}, \mathrm{m}, 5-\mathrm{H}_{2}, 6-\mathrm{H}\right), 1.57$ $\left(1 \mathrm{H}, \mathrm{m}, 6-\mathrm{H}^{\prime}\right), 1.54\left(3 \mathrm{H}, \mathrm{s}, 8-\mathrm{CH}_{3}\right), 1.34\left(3 \mathrm{H}, \mathrm{s}, 11-\mathrm{CH}_{3}\right), 1.25$ $\left(1 \mathrm{H}, \mathrm{m}, 13-\mathrm{H}^{\prime}\right), 1.20(1 \mathrm{H}, \mathrm{m}, \mathrm{OH}) 1.13\left(3 \mathrm{H}, \mathrm{s}, 4-\mathrm{CH}_{3}\right)$ and 0.99 $\left(1 \mathrm{H}, \mathrm{d}, J 7.3,12-\mathrm{CH}_{3}\right) ; \delta_{\mathrm{C}}\left(125 \mathrm{MHz}, \mathrm{CDCl}_{3}\right)$ 145.9, 140.6, $138.4,137.6,133.2,129.8,128.7,128.6,128.4,128.1,127.6$, $124.7,120.4,119.3,92.2,72.3,69.6,65.4,62.7,52.2,49.4,39.6$, $38.8,34.6,34.3,22.8,22.2,22.0,17.3$ and $16.2 ; \mathrm{m} / z\left(\mathrm{ES}^{+}\right) 587.5$ $\left(\mathrm{M}^{+}+23,100 \%\right)$; HRMS $\left(\mathrm{ES}^{+}\right): \mathrm{MNa}^{+}$, found 587.2798. $\mathrm{C}_{34} \mathrm{H}_{44} \mathrm{O}_{5} \mathrm{SNa}$ requires 587.2802.

4.2.2 (1SR,2RS, 11SR, 12RS, 14SR,3E, 7E)-15-Methylene4,8,11,12-tetramethylbicyclo[9.3.1]pentadeca-3,7-diene-2,14diol (14). The BOM-protected sulfone $13(0.38 \mathrm{~g}, 0.68 \mathrm{mmol})$ in THF $(8.09 \mathrm{~mL})$ and anhydrous ethanol $(55 \mu \mathrm{L})$ were added to liquid $\mathrm{NH}_{3}(12.4 \mathrm{~mL})$ at $-78^{\circ} \mathrm{C}$. Finely chopped sodium rinsed in light petroleum was added portionwise until the solution retained a blue colour. The cooling bath was then removed and the reaction allowed to reflux for $45 \mathrm{~min}$. Solid $\mathrm{NH}_{4} \mathrm{Cl}$ as added until the solution had lost the blue colour, the white residue was allowed to warm to $\mathrm{rt}$, and the ammonia was allowed to evaporate. Tetrahydrofuran $(5 \mathrm{~mL})$ was added, the mixture was filtered through a pad of cotton wool and the filtrate was concentrated under reduced pressure. The solid residue was dissolved in water $(5 \mathrm{~mL})$ and the solution washed with ethyl acetate $(5 \times 2.5 \mathrm{~mL})$ then added to the remaining residue from the filtration and the combined solution concentrated under reduced pressure. Chromatography of the residue (50:50 ether:light petroleum ether) gave the title compound $\mathbf{1 4}$ as an off white solid $(0.16 \mathrm{~g}, 75 \%), R_{f}=0.21$ ( $100 \%$ ether $), \mathrm{mp} 147-149{ }^{\circ} \mathrm{C} ; v_{\max } / \mathrm{cm}^{-1}$ 3368, 3082, 2961, 2920, 1660, 1624, 1447, 1381, 1074, 1020, 978, 903 and 733; $\delta_{\mathrm{H}}\left(500 \mathrm{MHz}, \mathrm{CDCl}_{3}\right) 5.14(1 \mathrm{H}, \mathrm{s}, 15-\mathrm{CH})$, $5.07(1 \mathrm{H}, \mathrm{d}, J 8.5,3-\mathrm{H}), 5.00\left(1 \mathrm{H}, \mathrm{s}, 15-\mathrm{CH}^{\prime}\right), 4.60(1 \mathrm{H}, \mathrm{m}, 7-\mathrm{H})$, $4.14(1 \mathrm{H}, \mathrm{m}, 2-\mathrm{H}), 4.04(1 \mathrm{H}, \mathrm{m}, 14-\mathrm{H}), 2.34(1 \mathrm{H}$, br. s, 2-OH $)$, $2.24(1 \mathrm{H}, \mathrm{d}, J 10.1,1-\mathrm{H}), 2.09-2.18\left(2 \mathrm{H}, \mathrm{m}, 6-\mathrm{H}_{2}\right), 1.88-2.01$ $\left(3 \mathrm{H}, \mathrm{m}, 5-\mathrm{H}_{2}, 14-\mathrm{OH}\right), 1.71-1.88\left(3 \mathrm{H}, \mathrm{m}, 9-\mathrm{H}_{2}, 10-\mathrm{H}\right), 1.58(1 \mathrm{H}$, dd, $J 12.3,6.6,13-\mathrm{H}), 1.47\left(3 \mathrm{H}, \mathrm{s}, 4-\mathrm{CH}_{3}\right), 1.44\left(3 \mathrm{H}, \mathrm{s}, 8-\mathrm{CH}_{3}\right)$, $1.28(1 \mathrm{H}, \mathrm{dq}, J 13.2,6.6,12-\mathrm{H}), 1.17\left(1 \mathrm{H}, \mathrm{m}, 13-\mathrm{H}^{\prime}\right), 0.80(3 \mathrm{H}$, d, $\left.J 6.6,12-\mathrm{CH}_{3}\right), 0.73\left(3 \mathrm{H}, \mathrm{s}, 11-\mathrm{CH}_{3}\right) 0.40\left(1 \mathrm{H}, \mathrm{m}, 10-\mathrm{H}^{\prime}\right) ; \delta_{\mathrm{C}}$ $\left(125 \mathrm{MHz}, \mathrm{CDCl}_{3}\right) 149.4,139.6,136.7,128.5,125.2,117.6$, $71.4,70.1,64.3,42.3,39.2,38.3,37.0,35.5,33.3,22.9,16.6$, 15.9(2) and 15.8; $\mathrm{m} / \mathrm{z}\left(\mathrm{ES}^{+}\right) 327.3\left(\mathrm{M}^{+}+23,80 \%\right)$; HRMS $\left(\mathrm{EI}^{+}\right)$: $\mathrm{M}^{+}$, found 304.2398. $\mathrm{C}_{20} \mathrm{H}_{32} \mathrm{O}_{2}$ requires 304.2397.

4.2.3 (1SR, 2SR, 3RS, 5RS, 12SR, 13RS, 15SR, 8E)-5,9, 12,13Tetramethyl-16-methylene-4-oxatricyclo[10.3.1.0 $\left.0^{3,5}\right]$ hexadec-8ene-2,15-diol (15). tert-Butyl hydroperoxide (5.5 M in decane, 14 $\mu \mathrm{L}, 0.079 \mathrm{mmol})$ was added to dihydroxytriene $14(20 \mathrm{mg}, 0.065$ 
$\mathrm{mmol})$ and $\mathrm{VO}(\mathrm{acac})_{2}(1.7 \mathrm{mg}, 0.0065 \mathrm{mmol})$ in benzene $(0.6$ $\mathrm{mL})$ at $\mathrm{rt}$ and the solution stirred at $\mathrm{rt}$ for $30 \mathrm{~min}$. Saturated aqueous $\mathrm{Na}_{2} \mathrm{SO}_{3}$ (2-3 drops) was added and the mixture was stirred for $10 \mathrm{~min}$, diluted with EtOAc $(5 \mathrm{~mL})$ and washed with saturated aqueous $\mathrm{NaHCO}_{3}(5 \mathrm{~mL})$. The aqueous phase was extracted with EtOAc $(4 \times 10 \mathrm{~mL})$ and the organic extracts were washed with brine $(10 \mathrm{~mL})$, dried $\left(\mathrm{Na}_{2} \mathrm{SO}_{4}\right)$ and concentrated under reduced pressure. Chromatography of the residue (70:30 ether:light petroleum) gave the title compound $\mathbf{1 5}$ as a white solid (18 mg, 85\%), $R_{f}=0.43$ (ether); $v_{\max } / \mathrm{cm}^{-1} 3430,3082,2960$, 2924, 1622, 1450, 1384, 1244, 1204, 1077, 1037, 1015, 910, 872, 799, 731 and $678 ; \delta_{\mathrm{H}}\left(500 \mathrm{MHz}, \mathrm{CDCl}_{3}\right) 5.22$ and $5.13($ each $1 \mathrm{H}$, s, 16-CH), $4.78(1 \mathrm{H}, \mathrm{dd}, J 10.4,1.3,8-\mathrm{H}), 4.14(1 \mathrm{H}, \mathrm{m}, 15-\mathrm{H})$, $3.47(1 \mathrm{H}$, br. d, $J 11.0,2-\mathrm{H}), 2.99(1 \mathrm{H}, \mathrm{s}, 3-\mathrm{H}), 2.60(1 \mathrm{H}, \mathrm{s}, 2-$ $\mathrm{OH}), 2.41(1 \mathrm{H}, \mathrm{d}, J 11.0,1-\mathrm{H}), 2.12(1 \mathrm{H}, \mathrm{m}, 7-\mathrm{H}), 2.03(1 \mathrm{H}, \mathrm{m}$, 6-H), 1.91-2.08 (2H, m, 7- $\left.\mathrm{H}^{\prime}, 15-\mathrm{OH}\right), 1.83-1.91\left(3 \mathrm{H}, \mathrm{m}, 10-\mathrm{H}_{2}\right.$, $11-\mathrm{H}), 1.58(1 \mathrm{H}, \mathrm{m}, 14-\mathrm{H}), 1.49\left(3 \mathrm{H}, \mathrm{s}, 9-\mathrm{CH}_{3}\right), 1.32(1 \mathrm{H}, \mathrm{m}, 13-$ $\mathrm{H}), 1.18-1.27\left(2 \mathrm{H}, \mathrm{m}, 14-\mathrm{H}^{\prime}, 6-\mathrm{H}^{\prime}\right), 1.12\left(3 \mathrm{H}, \mathrm{s}, 5-\mathrm{CH}_{3}\right), 0.87$ $\left(3 \mathrm{H}, \mathrm{d}, J 6.9,13-\mathrm{CH}_{3}\right), 0.81\left(1 \mathrm{H}, \mathrm{s}, 12-\mathrm{CH}_{3}\right)$ and $0.67(1 \mathrm{H}, \mathrm{m}, 11-$ $\left.\mathrm{H}^{\prime}\right) ; \delta_{\mathrm{C}}\left(125 \mathrm{MHz}, \mathrm{CDCl}_{3}\right) 148.4,137.1,124.0,119.4,71.1,65.6$, $63.8,62.3,42.6,38.2,37.8,36.9,36.5,32.9,29.7,23.8,19.2$, 17.0, 16.0 and 15.7; $\mathrm{m} / \mathrm{z}\left(\mathrm{ES}^{+}\right) 343.3\left(\mathrm{M}^{+}+23,60 \%\right)$; HRMS $\left(\mathrm{EI}^{+}\right)$: $\mathrm{M}^{+}$, found $320.2346 . \mathrm{C}_{20} \mathrm{H}_{32} \mathrm{O}_{3}$ requires 320.2346 .

4.2.4 (1RS,3SR,4RS,6SR)-3-Benzenesulfonylmethyl-6-tertbutyldiphenylsilyloxy-1-hydroxymethyl-3,4-dimethyl-2-

oxiranylcyclohexane (17). meta-Chloroperoxybenzoic acid $(77 \%$ in mineral oil, $40 \mathrm{mg}, 0.18 \mathrm{mmol}$ ) was added to the methylenecyclohexane $6(50 \mathrm{mg}, 0.088 \mathrm{mmol})$ in DCM $(1.03$ $\mathrm{mL}$ ) at $\mathrm{rt}$ and the solution stirred at $\mathrm{rt}$ for $3 \mathrm{~h}$. Dichloromethane $(10 \mathrm{~mL})$ was added and the solution washed with aqueous $\mathrm{NaOH}$ $(0.1 \mathrm{M}, 2 \times 4 \mathrm{~mL})$, water $(8 \mathrm{~mL})$ and brine $(8 \mathrm{~mL})$. The organic phase was dried $\left(\mathrm{Na}_{2} \mathrm{SO}_{4}\right)$ and concentrated under reduced pressure. Chromatography of the residue (60:40 ether:light petroleum) gave the title compound $\mathbf{1 7}$ as a glassy solid (45 $\mathrm{mg}$, $85 \%$ ), a 60:40 mixture of diastereoisomers ( ${ }^{1} \mathrm{H}$ NMR), $R_{f}=0.4$ (70\% ether in light petroleum); $v_{\max } / \mathrm{cm}^{-1} 3520,3071,2957,2932$, $2858,1588,1444,1428,1308,1150,1111,911,829,735$ and 704; $\delta_{\mathrm{H}}\left(500 \mathrm{MHz}, \mathrm{CDCl}_{3}\right)$ 7.74-7.77 (2H, m, ArH), 7.60-7.66 (4H, m, ArH), 7.54 (1H, m, ArH), 7.43-7.47 (2H, m, ArH), 7.27$7.41(6 \mathrm{H}, \mathrm{m}, \mathrm{ArH}), 3.84-3.90(1.6 \mathrm{H}, \mathrm{m}, 6-\mathrm{H}, 1-\mathrm{CH}), 3.71(0.4 \mathrm{H}$, $\left.\mathrm{m}, 1-\mathrm{CH}^{\prime}\right), 3.70\left(0.6 \mathrm{H}, \mathrm{dd}, J 11.7,2.4,1-\mathrm{CH}^{\prime}\right), 3.64(0.4 \mathrm{H}, \mathrm{m}, 6-$ $\mathrm{H}), 3.36(0.4 \mathrm{H}, \mathrm{m}, \mathrm{OH}), 3.21(0.6 \mathrm{H}, \mathrm{d}, J 2.4,2-\mathrm{CH}), 3.16(0.4 \mathrm{H}$, s, 2-CH), $3.15\left(0.6 \mathrm{H}, \mathrm{d}, J 2.4,2-\mathrm{CH}^{\prime}\right), 2.88(0.4 \mathrm{H}, \mathrm{d}, J 2.0,2-$ $\left.\mathrm{CH}^{\prime}\right), 2.84(0.4 \mathrm{H}, \mathrm{d}, J 15.3,3-\mathrm{CH}), 2.83(0.6 \mathrm{H}, \mathrm{d}, J 15.3,3-\mathrm{CH})$, $2.78\left(0.4 \mathrm{H}, \mathrm{d}, J 15.3,3-\mathrm{CH}^{\prime}\right), 2.55\left(0.6 \mathrm{H}, \mathrm{d}, J 15.3,3-\mathrm{CH}^{\prime}\right), 2.34$ $(0.4 \mathrm{H}, \mathrm{m}, 1-\mathrm{H}), 2.17(0.6 \mathrm{H}, \mathrm{m}, 1-\mathrm{H}), 1.90(0.4 \mathrm{H}, \mathrm{m}, 4-\mathrm{H}), 1.61$ $(0.6 \mathrm{H}, \mathrm{br} \mathrm{s}, \mathrm{OH}), 1.53(0.4 \mathrm{H}, \mathrm{dt}, J 13.3,4.3,5-\mathrm{H}), 1.34-1.42(4 \mathrm{H}$, m, 5-H, 5- $\left.\mathrm{H}^{\prime}, 3-\mathrm{CH}_{3}\right), 1.14-1.22\left(1.2 \mathrm{H}, \mathrm{m} 5-\mathrm{H}^{\prime}, 4-\mathrm{H}\right), 0.97[9 \mathrm{H}, \mathrm{s}$, $\left.\mathrm{SiC}\left(\mathrm{CH}_{3}\right)_{3}\right], 0.8\left(1.2 \mathrm{H}, \mathrm{d}, J 6.3,4-\mathrm{CH}_{3}\right)$ and $0.67(1.8 \mathrm{H}, \mathrm{d}, J 6.7$, $\left.4-\mathrm{CH}_{3}\right) ; \mathrm{m} / \mathrm{z}\left(\mathrm{ES}^{+}\right) 596.4\left(\mathrm{M}^{+}+18,100 \%\right)$; $\mathrm{HRMS}\left(\mathrm{ES}^{+}\right)$: $\mathrm{MNH}_{4}{ }^{+}$, found 596.2853. $\mathrm{C}_{33} \mathrm{H}_{46} \mathrm{O}_{5} \mathrm{NSSi}$ requires 596.2860.

4.2 .5 (1RS, 2RS,3SR,4RS,6SR)- and (1RS,2SR,3SR,4RS,6SR)3-Benzenesulfonylmethyl-6-tert-butyldiphenylsilyloxy-3,4-

dimethyl-2-oxiranylcyclohexanecarbaldehydes (18) and (19). Diisopropylethylamine $(0.205 \mathrm{~mL}, 1.17 \mathrm{mmol})$ was added to a mixture of isomers of the hydroxyepoxide $17(140 \mathrm{mg}, 0.27$ mmol) in DCM $(1 \mathrm{~mL})$ at $\mathrm{rt}$ and the solution cooled to $0{ }^{\circ} \mathrm{C}$ before the addition of the pyridine. $\mathrm{SO}_{3}(0.127 \mathrm{mg}, 0.803 \mathrm{mmol})$ in DMSO $(1.1 \mathrm{~mL})$. The solution was stirred at $0{ }^{\circ} \mathrm{C}$ for $15 \mathrm{~min}$ and then poured into brine $(3.5 \mathrm{~mL})$. The aqueous phase was extracted into ethyl acetate $(3 \times 15 \mathrm{~mL})$ and the organic extracts were washed with saturated aqueous $\mathrm{CuSO}_{4}(50 \mathrm{~mL})$, water $(50$ $\mathrm{mL})$ and brine $(50 \mathrm{~mL})$, then dried $\left(\mathrm{Na}_{2} \mathrm{SO}_{4}\right)$ and concentrated under reduced pressure. Chromatography of the residue (50:50 ether:light petroleum) gave the title compound $\mathbf{1 8}$ as a white solid
(55 mg, 40\%), mp $154-156{ }^{\circ} \mathrm{C}, R_{f}=0.49$ (50:50 ether:light petroleum); $v_{\max } / \mathrm{cm}^{-1} 3069,2933,2859,1729,1468,1449,1313$, $1150,1109,1041,912,825$ and $739 ; \delta_{\mathrm{H}}\left(500 \mathrm{MHz}, \mathrm{CDCl}_{3}\right) 9.22$ (1H, d, J 4.4, CHO), 7.84-7.89 (2H, m, ArH), 7.63-7.72 (5H, m, ArH), 7.54-7.59 (2H, m, Ar-H), 7.39-7.49 (6H, m, ArH), 4.37 $(1 \mathrm{H}, \mathrm{td}, J 10.7,4.8,6-\mathrm{H}), 3.24(1 \mathrm{H}, \mathrm{d}, J 2.4,2-\mathrm{CH}), 2.95(1 \mathrm{H}, \mathrm{d}$, $J$ 15.9, 3-CH), $2.89(1 \mathrm{H}, \mathrm{dd}, J 10.7,4.4,1-\mathrm{H}), 2.67(1 \mathrm{H}, \mathrm{d}, J$ 15.9, 3- $\left.\mathrm{CH}^{\prime}\right), 2.60\left(1 \mathrm{H}, \mathrm{d}, J 2.4,2-\mathrm{CH}^{\prime}\right), 1.69$ and $1.54($ each $1 \mathrm{H}$, $\mathrm{m}, 5-\mathrm{H}), 1.48\left(3 \mathrm{H}, \mathrm{s}, 3-\mathrm{CH}_{3}\right), 1.44(1 \mathrm{H}, \mathrm{m}, 4-\mathrm{H}), 1.03[9 \mathrm{H}, \mathrm{s}$, $\left.\mathrm{SiC}\left(\mathrm{CH}_{3}\right)_{3}\right]$ and $0.98\left(3 \mathrm{H}, \mathrm{d}, J 6.1,4-\mathrm{CH}_{3}\right) ; \delta_{\mathrm{C}}\left(125 \mathrm{MHz}, \mathrm{CDCl}_{3}\right)$ 203.4, 141.7, 136.2, 136.1, 134.2, 133.9, 133.1, 130.4, 130.1, $129.6,128.1,127.9,127.7,69.8,61.8,56.6,56.0,47.6,42.4$, $37.6,37.0,27.1,19.4,16.6$ and 13.7. The second fraction was the title compound 19 as a white solid, (35 mg, 25\%), $R_{f}=0.41$ (50:50 ether:light petroleum); $v_{\max } / \mathrm{cm}^{-1} 3069,2930,2857,1729$, $1466,1451,1314,1151,1109,1039,911,825$ and $737 ; \delta_{\mathrm{H}}(500$ $\left.\mathrm{MHz}, \mathrm{CDCl}_{3}\right) 9.51(1 \mathrm{H}, \mathrm{d}, J 3.0, \mathrm{CHO}), 7.83-7.87$ (2H, m, ArH), 7.68-7.74 (4H, m, ArH), $7.65(1 \mathrm{H}, \mathrm{m}, \mathrm{ArH}), 7.55-7.60(2 \mathrm{H}, \mathrm{m}$, ArH), 7.41-7.52 (6H, m, ArH), 4.38 (1H, td, J 8.9, 4.6, 6-H), 3.27 $(1 \mathrm{H}, \mathrm{dd}, J 2.4,1.0,2-\mathrm{CH}), 2.96(1 \mathrm{H}, \mathrm{d}, J 13.5,3-\mathrm{CH}), 2.89(1 \mathrm{H}$, m, 1-H), $2.89\left(1 \mathrm{H}, \mathrm{d}, J 13.5,3-\mathrm{CH}^{\prime}\right), 2.75\left(1 \mathrm{H}, \mathrm{d}, J 2.4,2-\mathrm{CH}^{\prime}\right)$, $2.07(1 \mathrm{H}, \mathrm{m}, 4-\mathrm{H}), 1.76(1 \mathrm{H}, \mathrm{dt}, J 13.5,4.5,5-\mathrm{H}), 1.59(1 \mathrm{H}, \mathrm{m}, 5-$ $\left.\mathrm{H}^{\prime}\right), 1.23\left(3 \mathrm{H}, \mathrm{s}, 3-\mathrm{CH}_{3}\right), 1.09\left(3 \mathrm{H}, \mathrm{d}, J 6.5,4-\mathrm{CH}_{3}\right)$ and $1.06[9 \mathrm{H}$, $\left.\mathrm{s}, \mathrm{SiC}\left(\mathrm{CH}_{3}\right)_{3}\right] ; \delta_{\mathrm{C}}\left(125 \mathrm{MHz}, \mathrm{CDCl}_{3}\right) 200.8,142.0,136.2,136.1$, $134.2,133.9,133.4,130.3,130.1,129.7,128.1,127.9,127.6$, $69.0,60.7,59.1,59.2,49.0,44.0,37.8,34.6,27.1,19.4,17.7$ and $17.5 ; \mathrm{m} / \mathrm{z}\left(\mathrm{ES}^{+}\right) 599\left(\mathrm{M}^{+}+23,80 \%\right)$ and $179(100)$; HRMS $\left(\mathrm{ES}^{+}\right)$: $\mathrm{MNa}^{+}$, found 599.2256. $\mathrm{C}_{33} \mathrm{H}_{40} \mathrm{O}_{5} \mathrm{SSiNa}$ requires 599.2258.

4.2.6 (1RS,3SR,4RS, 6SR)-1-[(1SR,2RS,3RS, 6E)-8-tertButyldimethylsilyloxy-3,7-dimethyl-2,3-epoxy-1-hydroxyoct-6-en1-yl]-3-benzenesulfonylmethyl-6-tert-butyldiphenylsilyloxy-3,4dimethyl-2-methylenecyclohexane (21). tert-Butyl hydroperoxide (5.5 $\mathrm{M}$ in decane, $20 \mu \mathrm{L}, 0.108 \mathrm{mmol}$ ) was added to the hydroxytriene $7(20 \mathrm{mg}, 0.024 \mathrm{mmol})$ and $\mathrm{VO}(\text { acac })_{2}(1 \mathrm{mg}$, $0.004 \mathrm{mmol})$ in benzene $(0.18 \mathrm{~mL})$ at $\mathrm{rt}$ and the solution was stirred at $\mathrm{rt}$ for $10 \mathrm{~min}$. Saturated aqueous $\mathrm{Na}_{2} \mathrm{SO}_{3}$ (2-3 drops) was added and the mixture was stirred for $10 \mathrm{~min}$ then diluted with EtOAc $(5 \mathrm{~mL})$ and washed with saturated aqueous $\mathrm{NaHCO}_{3}$ $(5 \mathrm{~mL})$. The aqueous phase was extracted with EtOAc $(4 \times 10$ $\mathrm{mL})$ and the organic extracts were washed with brine $(10 \mathrm{~mL})$, dried $\left(\mathrm{Na}_{2} \mathrm{SO}_{4}\right)$, and concentrated under reduced pressure. Chromatography of the residue (70:30 ether:light petroleum) gave the title compound $\mathbf{2 1}$ as a white foam (16 $\mathrm{mg}, 78 \%$ ) containing $10 \%$ of a minor isomer $\left({ }^{1} \mathrm{H}\right.$ NMR), $R_{f}=0.50(50: 50$ ether:light petroleum); $v_{\max } / \mathrm{cm}^{-1} 3479,3071,2957,2931,1631$, 1589, 1462, 1448, 1428, 1309, 1255, 1149, 1108, 1083, 910, 837, 776, 741 and $704 ; \delta_{\mathrm{H}}\left(500 \mathrm{MHz}, \mathrm{CDCl}_{3}\right) 7.76-7.79(2 \mathrm{H}, \mathrm{m}, \mathrm{ArH})$, 7.61-7.65 (4H, m, ArH), $7.52(1 \mathrm{H}, \mathrm{m}, \mathrm{ArH}), 7.43-7.46(2 \mathrm{H}, \mathrm{m}$, $\mathrm{ArH}), 7.28-7.37(6 \mathrm{H}, \mathrm{m}, \mathrm{ArH}), 5.25\left(1 \mathrm{H}, \mathrm{m}, 6^{\prime}-\mathrm{H}\right), 5.19$ and 5.04 (each 1H, s, 2-CH), $4.09(1 \mathrm{H}, \mathrm{m}, 6-\mathrm{H}), 3.94\left(2 \mathrm{H}, \mathrm{s}, 8^{\prime}-\mathrm{H}_{2}\right), 3.70$ $\left(1 \mathrm{H}, \mathrm{m}, 1^{\prime}-\mathrm{H}\right), 3.42$ and 3.34 (each $\left.1 \mathrm{H}, \mathrm{d}, J 14.5,3-\mathrm{CH}\right), 2.66$ $\left(1 \mathrm{H}, \mathrm{d}, J 6.3,2^{\prime}-\mathrm{H}\right), 2.52(1 \mathrm{H}, \mathrm{m}, 1-\mathrm{H}), 2.26(1 \mathrm{H}, \mathrm{d}, J 3.8, \mathrm{OH})$, $1.95\left(2 \mathrm{H}, \mathrm{m}, 5^{\prime}-\mathrm{H}_{2}\right), 1.75(1 \mathrm{H}, \mathrm{m}, 4-\mathrm{H}), 1.67(1 \mathrm{H}, \mathrm{dt}, J 14.2,4.41$, 5-H), $1.51\left(3 \mathrm{H}, \mathrm{s}, 7^{\prime}-\mathrm{CH}_{3}\right), 1.45\left(1 \mathrm{H}, \mathrm{m}, 5-\mathrm{H}^{\prime}\right), 1.32\left(3 \mathrm{H}, \mathrm{s}, 3^{\prime}-\right.$ $\left.\mathrm{CH}_{3}\right), 1.31-1.34\left(2 \mathrm{H}, \mathrm{m}, 4{ }^{\prime}-\mathrm{CH}_{2}\right), 1.16\left(3 \mathrm{H}, \mathrm{s}, 3-\mathrm{CH}_{3}\right), 0.95$ and 0.84 [each $\left.9 \mathrm{H}, \mathrm{s}, \mathrm{SiC}\left(\mathrm{CH}_{3}\right)_{3}\right], 0.79\left(3 \mathrm{H}, \mathrm{d}, J 6.9,4-\mathrm{CH}_{3}\right)$ and 0.00 $\left(6 \mathrm{H}, \mathrm{s}, 2 \times \mathrm{SiCH}_{3}\right) ; \delta_{\mathrm{C}}\left(125 \mathrm{MHz}, \mathrm{CDCl}_{3}\right) 149.6,142.5,135.9(2)$, $134.9,134.1,133.7,133.3,129.8,129.2,127.7,127.6,127.3$, $123.4,71.4,70.2,68.5,65.0,62.4,43.9,38.1,36.3,27.0,26.0$, $23.1,21.3,19.2,18.4,17.1,16.7,13.5$ and $-5.2 ; \mathrm{m} / z\left(\mathrm{ES}^{-}\right) 867.5$ $\left([\mathrm{M}+35]^{-}, 65 \%\right)$ and $865.5\left([\mathrm{M}+35]^{-}, 100\right)$ : HRMS $\left(\mathrm{ES}^{+}\right)$: $\mathrm{MNa}^{+}$, found 853.4335. $\mathrm{C}_{48} \mathrm{H}_{70} \mathrm{O}_{6} \mathrm{SSi}_{2} \mathrm{Na}$ requires 853.4324.

4.2.7 (1RS,3SR,4RS,6SR)-1-[(1SR, 2RS,3RS)-8-tertButyldimethylsilyloxy-3,7-dimethyl-2,3,6,7-bisepoxy-1hydroxyoct-1-yl]-3-benzenesulfonylmethyl-6-tert- 
butyldiphenylsilyloxy-3,4-dimethyl-2-methylenecyclohexane (22). meta-Chloroperoxybenzoic acid (77\% in mineral oil, $7 \mathrm{mg}, 0.029$ mmol) was aded to the hydroxytriene $7(20 \mathrm{mg}, 0.025 \mathrm{mmol})$ in DCM $(0.36 \mathrm{~mL})$ at $\mathrm{rt}$ and the solution was stirred at $\mathrm{rt}$ for $1.5 \mathrm{~h}$. More meta-chloroperoxybenzoic acid (77\% in mineral oil, $3 \mathrm{mg}$, $0.013 \mathrm{mmol}$ ) was added and the solution stirred at $\mathrm{rt}$ for $1 \mathrm{~h}$. Dichloromethane $(5 \mathrm{~mL})$ was added and the solution washed with aqueous $\mathrm{NaOH}(0.1 \mathrm{M}, 2 \times 4 \mathrm{~mL})$, water $(4 \mathrm{~mL})$ and brine $(4 \mathrm{~mL})$. The organic phase was dried $\left(\mathrm{Na}_{2} \mathrm{SO}_{4}\right)$ and concentrated under reduced pressure. Chromatography of the residue (30:70 ether:light petroleum) gave the monoepoxide 21 (3.5 mg, 15\%) followed by the title compound $\mathbf{2 2}$ as a white foam ( $9 \mathrm{mg}, 48 \%)$, a 55:45 mixture of diastereoisomers with other very minor isomers ( ${ }^{1} \mathrm{H}$ NMR), $R_{f}=0.24$ (70:30 ether: light petroleum); $v_{\max } / \mathrm{cm}^{-1} 3477,3071,2957,2930,2857,1726,1631,1588,1470$, $1448,1428,1387,1308,1256,1106,1085,909,838,778,742$ and $704 ; \delta_{\mathrm{H}}\left(500 \mathrm{MHz}, \mathrm{CDCl}_{3}\right) 7.77-7.80(2 \mathrm{H}, \mathrm{m}, \mathrm{ArH}), 7.62-$ 7.66 (4H, m, ArH), 7.54 (1H, m, ArH), 7.44-7.47 (2H, m, ArH), 7.30-7.38 $(6 \mathrm{H}, \mathrm{m}, \mathrm{ArH}), 5.20$ and $5.02($ each $1 \mathrm{H}, \mathrm{s}, 2-\mathrm{CH}), 4.10$ $(1 \mathrm{H}, \mathrm{m}, 6-\mathrm{H}), 3.74\left(1 \mathrm{H}, \mathrm{m}, 1^{\prime}-\mathrm{H}\right), 3.51-3.52\left(2 \mathrm{H}, \mathrm{m}, 8^{\prime}-\mathrm{H}_{2}\right), 3.41$ and 3.35 (each $1 \mathrm{H}, \mathrm{d}, J 14.5,3-\mathrm{CH}), 2.70-2.76\left(2 \mathrm{H}, \mathrm{m}, 2^{\prime}-\mathrm{H}\right.$, $\mathrm{OH}), 2.54(1 \mathrm{H}, \mathrm{m}, 1-\mathrm{H}), 2.40\left(0.55 \mathrm{H}, \mathrm{m}, 6^{\prime}-\mathrm{H}\right), 2.34(0.45 \mathrm{H}, \mathrm{m}$, $\left.6^{\prime}-\mathrm{H}\right), 1.73(1 \mathrm{H}, \mathrm{m}, 4-\mathrm{H}), 1.67(1 \mathrm{H}, \mathrm{dt}, 14.2,4.7,5-\mathrm{H}), 1.35-1.51$ $\left(5 \mathrm{H}, \mathrm{m}, 5-\mathrm{H}^{\prime}, 4^{\prime}-\mathrm{H}_{2}, 5^{\prime}-\mathrm{H}_{2}\right), 1.32\left(3 \mathrm{H}, \mathrm{s}, 3-\mathrm{CH}_{3}\right), 1.18-1.20(6 \mathrm{H}$, $\left.\mathrm{m}, 3^{\prime}-\mathrm{CH}_{3}, 7^{\prime}-\mathrm{CH}_{3}\right), 0.96$ and 0.83 [each $9 \mathrm{H}, \mathrm{s}, \mathrm{SiC}\left(\mathrm{CH}_{3}\right)_{3}$ ], 0.78 $\left(3 \mathrm{H}, \mathrm{d}, J 6.6,4-\mathrm{CH}_{3}\right)$ and -0.01 and -0.02 (each $\left.3 \mathrm{H}, \mathrm{s}, \mathrm{SiCH}_{3}\right)$; $m / z\left(\mathrm{ES}^{+}\right) 869.8\left(\mathrm{M}^{+}+23,100 \%\right)$; HRMS $\left(\mathrm{ES}^{+}\right): \mathrm{MNa}^{+}$found 869.4271. $\mathrm{C}_{48} \mathrm{H}_{70} \mathrm{O}_{7} \mathrm{SSi}_{2} \mathrm{Na}$ requires 869.4273.

4.2.8 (1RS,3SR,4RS, 6SR)-1-[(1SR, 2RS, 3RS, 6E)-8-tertButyldimethylsilyloxy-3,7-dimethyl-2,3-epoxy-1-hydroxyoct-6-en1-yl]-3-benzenesulfonylmethyl-6-tert-butyldiphenylsilyloxy-3,4dimethyl-2-oxiranylcyclohexane (23). tert-Butyl hydroperoxide (5.5 $\mathrm{M}$ in decane, $44 \mu \mathrm{L}, 0.245 \mathrm{mmol}$ ) was added to the hydroxytriene $7(20 \mathrm{mg}, 0.024 \mathrm{mmol})$ and $\mathrm{VO}(\mathrm{acac})_{2}(1 \mathrm{mg}$, $0.004 \mathrm{mmol})$ in $\mathrm{DCM}(0.2 \mathrm{~mL})$ at $\mathrm{rt}$ and the solution heated at 60 ${ }^{\circ} \mathrm{C}$ in a microwave reactor for $1 \mathrm{~h}$. Saturated aqueous $\mathrm{Na}_{2} \mathrm{SO}_{3}(2-3$ drops) was added, the mixture was stirred at $\mathrm{rt}$ for $10 \mathrm{~min}$, and EtOAc $(5 \mathrm{~mL})$ was added. The solution washed with saturated aqueous $\mathrm{NaHCO}_{3}(5 \mathrm{~mL})$ and the aqueous phase was extracted with EtOAc $(4 \times 10 \mathrm{~mL})$. The organic extracts were washed with brine $(10 \mathrm{~mL})$, dried $\left(\mathrm{Na}_{2} \mathrm{SO}_{4}\right)$, and concentrated under reduced pressure. Chromatography of the residue (20:80 to $30: 70$ ether:light petroleum) gave the title compound $\mathbf{2 3}$ as yellow gum $(12 \mathrm{mg}, 57 \%) ; R_{f}=0.22$ (50:50 ether:light petroleum); $v_{\max } / \mathrm{cm}^{-1}$ 3483, 3071, 2957, 2930, 2857, 1726, 1686, 1588, 1462, 1447, $1428,1388,1320,1253,1152,1110,1084,837,778,741$ and $704 ; \delta_{\mathrm{H}}\left(500 \mathrm{MHz}, \mathrm{CDCl}_{3}\right)$ 7.77-7.67 $(6 \mathrm{H}, \mathrm{m}, \mathrm{ArH}), 7.53(1 \mathrm{H}, \mathrm{m}$, ArH), 7.44-7.47 (2H, m, ArH), 7.41-7.31 (6H, m, ArH), 5.30 $\left(1 \mathrm{H}, \mathrm{m}, 6^{\prime}-\mathrm{H}\right), 4.12(1 \mathrm{H}, \mathrm{dt}, J 10.4,4.4,6-\mathrm{H}), 3.95\left(2 \mathrm{H}, \mathrm{s}, 8^{\prime}-\mathrm{H}_{2}\right)$, $3.38\left(1 \mathrm{H}, \mathrm{m}, 1^{\prime}-\mathrm{H}\right), 3.32\left(1 \mathrm{H}, \mathrm{m}, 2^{\prime}-\mathrm{H}\right), 3.04(1 \mathrm{H}, \mathrm{m}, 2-\mathrm{CH})$, 2.91-2.95 (2H, m, 2-CH', 3-CH), $2.84\left(1 \mathrm{H}, \mathrm{d}, J 14.8,3-\mathrm{CH}^{\prime}\right)$, 2.05-2.11 (3H, m, 1-H, 5'- $\left.\mathrm{H}_{2}\right), 1.74(1 \mathrm{H}, \mathrm{m}, 4-\mathrm{H}), 1.53\left(3 \mathrm{H}, \mathrm{s}, 7^{\prime}-\right.$ $\left.\mathrm{CH}_{3}\right), 1.39-1.60\left(4 \mathrm{H}, \mathrm{m}, 5-\mathrm{H}_{2}, 4^{\prime}-\mathrm{H}_{2}\right), 1.24\left(3 \mathrm{H}, \mathrm{s}, 3^{\prime}-\mathrm{CH}_{3}\right), 0.98$ and 0.85 [each $9 \mathrm{H}, \mathrm{s}, \mathrm{SiC}\left(\mathrm{CH}_{3}\right)_{3}$ ] $0.84\left(3 \mathrm{H}, \mathrm{s}, 3-\mathrm{CH}_{3}\right), 0.76(3 \mathrm{H}$, $\left.\mathrm{d}, J 6.9,4-\mathrm{CH}_{3}\right)$ and $0.00\left(6 \mathrm{H}, \mathrm{s}, 2 \times \mathrm{SiCH}_{3}\right) ; \delta_{\mathrm{C}}(125 \mathrm{MHz}$, $\left.\mathrm{CDCl}_{3}\right)$ 142.2, 135.8, 135.7, 135.1, 134.5, 133.4, 133.0, 130.0, $129.7,129.3,127.9,127.6,127.3,123.3,68.5,67.4,66.7,61.7$, $61.1,60.4,49.1,43.9,38.7,29.7,27.1,26.6,26.0,25.8,25.7$, 23.5, 19.3, 18.4, 17.2, 16.7, 13.5 and $-5.2 ; \mathrm{m} / \mathrm{z}\left(\mathrm{ES}^{+}\right) 906.2$ $(100 \%)$ and $869.7\left(\mathrm{M}^{+}+23,82\right)$; HRMS $\left(\mathrm{ES}^{+}\right): \mathrm{MNa}^{+}$found 869.4294. $\mathrm{C}_{48} \mathrm{H}_{70} \mathrm{O}_{7} \mathrm{SSi}_{2} \mathrm{Na}$ requires 869.4273.

4.2.9 (1SR,2SR,3RS, 5RS, 13SR, 14RS, 16SR)-5, 10,13,14Tetramethyl-17-methylene-4,9-bisoxatetracyclo[11.3.1. $\left.0^{3,5} \cdot 0^{8,10}\right]$ heptadecane-2,16-diol Following the procedure outlined for the synthesis of the bis- epoxide 23, the dihydroxytriene 14 (20 $\mathrm{mg}, 0.064 \mathrm{mmol})$, $\mathrm{VO}(\mathrm{acac})_{2}(2.6 \mathrm{mg}, 0.010 \mathrm{mmol})$ in $\mathrm{DCM}(0.53 \mathrm{~mL})$ and tertbutyl hydroperoxide $(5.5 \mathrm{M}$ in decane, $0.12 \mathrm{~mL}, 0.66 \mathrm{mmol})$, after heating in a microwave reactor at $60{ }^{\circ} \mathrm{C}$ for $0.5 \mathrm{~h}$ and chromatography (70:30 to 80:20 ether:light petroleum), gave firstly the monoepoxide $\mathbf{1 5}$ as a thin clear film (3 mg, 13\%) containing ca. $25 \%$ of a minor diastereoisomer, $\mathrm{R}_{f}=0.42$ (ether); HRMS $\left(\mathrm{EI}^{+}\right)$: $\mathrm{M}^{+}$, found 320.2346. $\mathrm{C}_{20} \mathrm{H}_{32} \mathrm{O}_{3}$ requires 320.2346 . The second fraction was the title compound $\mathbf{2 4}$ as a white foam (7 $\mathrm{mg}, 31 \%$ ), a 9:1 mixture of diastereoisomers ( $\left.{ }^{1} \mathrm{H} \mathrm{NMR}\right), R_{f}=$ 0.24 (ether); $v_{\max } / \mathrm{cm}^{-1} 3436,3082,2960,2929,2360,1722,1625$, $1453,1422,1387,1304,1249,1075,1027,917,796$ and $732 ; \delta_{\mathrm{H}}$ $\left(500 \mathrm{MHz}, \mathrm{CDCl}_{3}\right.$ ) major diastereoisomer 5.12 and 5.00 (each $1 \mathrm{H}, \mathrm{s}, 17-\mathrm{CH}), 4.30$ (1H, dd, $J 10.7,7.2,16-\mathrm{H}), 3.56$ (1H, dd, $J$ 11.7, 4.4, 2-H), $2.96(1 \mathrm{H}, \mathrm{d}, J 4.4,3-\mathrm{H}), 2.65(1 \mathrm{H}, \mathrm{s}, 2-\mathrm{OH}), 2.39$ (1H, m, 1-H), $2.38(1 \mathrm{H}, \mathrm{d}, J$ 9.4, 8-H), $2.19(1 \mathrm{H}, \mathrm{dt}, J 13.6,3.5$, $15-\mathrm{H}) 1.80-1.90\left(3 \mathrm{H}, \mathrm{m}, 11-\mathrm{H}, 7-\mathrm{H}_{2}\right), 1.63-1.68\left(3 \mathrm{H}, \mathrm{m}, 11-\mathrm{H}^{\prime}\right.$, 6- $\left.\mathrm{H}_{2}\right), 1.52(1 \mathrm{H}, \mathrm{s}, 16-\mathrm{OH}), 1.39(1 \mathrm{H}, \mathrm{m}, 14-\mathrm{H}), 1.26(1 \mathrm{H}, \mathrm{m}, 15-$ $\left.\mathrm{H}^{\prime}\right), 1.19\left(3 \mathrm{H}, \mathrm{s}, 10-\mathrm{CH}_{3}\right), 1.15\left(3 \mathrm{H}, \mathrm{s}, 5-\mathrm{CH}_{3}\right), 0.97(1 \mathrm{H}, \mathrm{dd}, J$ $13.0,9.8,12-\mathrm{H}), 0.84\left(3 \mathrm{H}, \mathrm{d}, J 6.914-\mathrm{CH}_{3}\right), 0.74(3 \mathrm{H}, \mathrm{s}, 13-$ $\left.\mathrm{CH}_{3}\right), 0.57\left(1 \mathrm{H}, \mathrm{dd}, J 13.0,9.8,12-\mathrm{H}^{\prime}\right)$; minor diastereoisomer 5.22 and 5.03 (each $1 \mathrm{H}, \mathrm{s}, 17-\mathrm{CH}), 4.20(1 \mathrm{H}, \mathrm{m}, 16-\mathrm{H})$ and 3.66 $(1 \mathrm{H}, \mathrm{m}, 2-\mathrm{H}) ; \mathrm{m} / z\left(\mathrm{ES}^{+}\right) 359.4\left(\mathrm{M}^{+}+23,100 \%\right)$; HRMS $\left(\mathrm{ES}^{+}\right)$: $\mathrm{MNa}^{+}$, found 359.2201. $\mathrm{C}_{20} \mathrm{H}_{32} \mathrm{O}_{4} \mathrm{Na}$ requires 359.2193.

4.2.10 (3RS, 5RS, 12SR,13RS,8E)-5,9,12,13-Tetramethyl-16methylene-4-oxatricyclo[10.3.1.0 $\left.0^{3,5}\right]$ hexadeca-1,8-dien-15-one (28). Di-isopropylethylamine ( $35 \mu \mathrm{L}, 0.21 \mathrm{mmol})$ was added to the dihydroxyepoxide $15(15 \mathrm{mg}, 0.046 \mathrm{mmol})$ in DCM $(0.17$ $\mathrm{mL}$ ) at $\mathrm{rt}$, the solution was cooled to to $-7{ }^{\circ} \mathrm{C}$, and the pyridine. $\mathrm{SO}_{3}$ complex $(30 \mathrm{mg}, 0.19 \mathrm{mmol}$ ) was added in DMSO $(0.19 \mathrm{~mL})$. The reaction mixture was stirred at $-7^{\circ}$ for $5 \mathrm{~min}$ then poured into brine $(3 \mathrm{~mL})$. The aqueous phase was extracted with EtOAc $(4 \times 6 \mathrm{~mL})$ and the organic extracts washed with saturated aqueous $\mathrm{CuSO}_{4}(10 \mathrm{~mL})$, water $(10 \mathrm{~mL})$ and brine $(10 \mathrm{~mL})$, then dried $\left(\mathrm{MgSO}_{4}\right)$ and concentrated under reduced pressure. Chromatography of the residue (80:20 ether:light petroleum to ether) gave the title compound $\mathbf{2 8}$ as a clear colourless oil $(7 \mathrm{mg}$, $50 \%) ; v_{\max } / \mathrm{cm}^{-1} 2918,2851,1694,1618,1453,1384,1230,1183$, 1062,908 and $863 ; \delta_{\mathrm{H}}\left(500 \mathrm{MHz}, \mathrm{CDCl}_{3}\right) 6.01(1 \mathrm{H}, \mathrm{d}, J 9.8,2-$ $\mathrm{H}), 5.36$ and 5.03 (each $1 \mathrm{H}, \mathrm{s}, 16-\mathrm{CH}), 4.85(1 \mathrm{H}, \mathrm{m}, 8-\mathrm{H}), 3.61$ $(1 \mathrm{H}, \mathrm{d}, J 9.8,3-\mathrm{H}), 2.72(1 \mathrm{H}, \mathrm{dd}, J 16.7,5.7,14-\mathrm{H}), 2.22(1 \mathrm{H}$, dd, $\left.J 16.7,3.2,14-\mathrm{H}^{\prime}\right), 2.09-2.17(2 \mathrm{H}, \mathrm{m}, 7-\mathrm{H}, 10-\mathrm{H}), 2.05(1 \mathrm{H}$, $\mathrm{dt}, J 12.9,3.5,11-\mathrm{H}), 1.98\left(1 \mathrm{H}, \mathrm{m}, 10-\mathrm{H}^{\prime}\right), 1.91(1 \mathrm{H}, \mathrm{dt}, J 10.1$, $\left.4.1,7-\mathrm{H}^{\prime}\right) 1.78(1 \mathrm{H}, \mathrm{dqd}, J 13.6,6.9,3.2,13-\mathrm{H}), 1.71(1 \mathrm{H}, \mathrm{dt}, J$ $13.9,4.1,6-\mathrm{H}), 1.50\left(1 \mathrm{H}, \mathrm{m}, 6-\mathrm{H}^{\prime}\right), 1.48\left(3 \mathrm{H}, \mathrm{s}, 9-\mathrm{CH}_{3}\right), 1.14$ $\left(3 \mathrm{H}, \mathrm{s}, 5-\mathrm{CH}_{3}\right), 1.05\left(1 \mathrm{H}, \mathrm{m}, 11-\mathrm{H}^{\prime}\right), 1.05\left(3 \mathrm{H}, \mathrm{s}, 12-\mathrm{CH}_{3}\right)$ and $0.84\left(3 \mathrm{H}, \mathrm{d}, J 6.9,13-\mathrm{CH}_{3}\right) ; \delta_{\mathrm{C}}\left(125 \mathrm{MHz}, \mathrm{CDCl}_{3}\right), 199.1,144.2$, $143.8,134.9,133.4,123.8,114.3,62.7,59.2,43.2,38.1,37.8$, $34.1,33.2,28.7,23.4,19.2,16.0,15.2$ and $14.3 ; \mathrm{m} / z\left(\mathrm{ES}^{+}\right) 301$ $\left(\mathrm{M}^{+}+1,100 \%\right)$; HRMS $\left(\mathrm{EI}^{+}\right): \mathrm{M}^{+}$, found 300.2085. $\mathrm{C}_{20} \mathrm{H}_{28} \mathrm{O}_{2}$ requires 300.2084 .

4.2.11 (2RS, 10SR, 11SR, 12RS, 3E, 7E)-10-Benzenesulfonyl-2benzyloxymethoxy-4,8,11,12-tetramethyl-14-

oxobicyclo[9.3.1]pentadeca-1(15),3,7-triene-15-carbaldehyde (29). $N$-Methylmorpholine- $N$-oxide $(10 \mathrm{mg}, 0.088 \mathrm{mmol})$ was added to a suspension of the alcohol $13(10 \mathrm{mg}, 0.017 \mathrm{mmol})$ and $4 \AA$ molecular sieves $(8 \mathrm{mg})$ in DCM $(0.41 \mathrm{~mL})$ and the mixture was stirred for $10 \mathrm{~min}$ at rt. Tetra- $n$-propylammonium perruthenate $(1 \mathrm{mg}, 0.0026 \mathrm{mmol})$ in DCM $(0.1 \mathrm{~mL})$ was added and the mixture stirred for $1 \mathrm{~h}$. Dichloromethane $(1 \mathrm{~mL})$ was added and the mixture was filtered through celite with copious washings of ether. The filtrate was washed with aqueous $\mathrm{Na}_{2} \mathrm{~S}_{2} \mathrm{O}_{3}$ $(20 \mathrm{~mL})$ and brine $(20 \mathrm{~mL})$, and the aqueous layer was extracted with ether $(1 \times 30 \mathrm{~mL})$. The organic extracts were dried $\left(\mathrm{MgSO}_{4}\right)$ and concentrated under reduced pressure. Chromatography of the 
residue (40:60 ether:light petroleum) gave the title compound 29 as a yellow viscous oil $(8 \mathrm{mg}, 78 \%), R_{f}=0.39$ (40:60 ether:light petroleum); $v_{\max } / \mathrm{cm}^{-1} 3066,2923,1675,1449,1303$, $1146,1026,911$ and $729 ; \delta_{\mathrm{H}}\left(500 \mathrm{MHz}, \mathrm{CDCl}_{3}\right) 10.58(1 \mathrm{H}, \mathrm{s}, 15-$ CHO), 7.8-7.82 (2H, m, ArH), 7.57 (1H, m, ArH), 7.47-7.50 (2H, $\mathrm{m}, \operatorname{ArH}), 7.19-7.29(5 \mathrm{H}, \mathrm{m}, \mathrm{ArH}), 5.76(1 \mathrm{H}, \mathrm{d}, J 9.5,2-\mathrm{H}), 4.98$ $(1 \mathrm{H}, \mathrm{d}, J 9.5,3-\mathrm{H}), 4.69$ and 4.63 (each $1 \mathrm{H}, \mathrm{d}, J 6.9, \mathrm{OHCHO})$, $4.57(1 \mathrm{H}, \mathrm{m}, 7-\mathrm{H}), 4.48$ and 4.43 (each $1 \mathrm{H}, \mathrm{d}, J 11.7, \mathrm{PhHCH})$, $3.61(1 \mathrm{H}, \mathrm{m}, 12-\mathrm{H}), 3.43(1 \mathrm{H}, \mathrm{d}, J 6.6,10-\mathrm{H}), 3.13(1 \mathrm{H}, \mathrm{dd}, J$ 16.7, 7.3, 9-H), 3.08 (1H, dd, $J 19.9,5.7,13-\mathrm{H}), 2.44$ (1H, d, $J$ 16.7, 9- $\left.\mathrm{H}^{\prime}\right), 2.41\left(1 \mathrm{H}, \mathrm{dd}, J 19.9,5.7,13-\mathrm{H}^{\prime}\right), 1.98(1 \mathrm{H}, \mathrm{m}, 6-\mathrm{H})$, 1.85-1.94 (2H, m, 5- $\left.\mathrm{H}_{2}\right), 1.74\left(1 \mathrm{H}, \mathrm{m}, 6-\mathrm{H}^{\prime}\right), 1.53\left(3 \mathrm{H}, \mathrm{s}, 8-\mathrm{CH}_{3}\right)$, $1.39\left(3 \mathrm{H}, \mathrm{s}, 4-\mathrm{CH}_{3}\right), 0.98\left(3 \mathrm{H}, \mathrm{d}, J 7.0,12-\mathrm{CH}_{3}\right)$ and $0.47(3 \mathrm{H}, \mathrm{s}$, $\left.11-\mathrm{CH}_{3}\right) ; \delta_{\mathrm{C}}\left(125 \mathrm{MHz}, \mathrm{CDCl}_{3}\right) 197.8,197.2,151.0,146.9$, $139.9,138.2,137.5,133.9,131.2,129.6,129.3,129.0,128.4$, $128.0,127.8,126.2,92.8,69.7,67.7,65.0,46.34,42.2,38.1$, $35.8,35.4,25.6,21.0,16.5,15.7$ and $13.5 ; \mathrm{m} / z\left(\mathrm{ES}^{+}\right) 594.5\left(\mathrm{M}^{+}+\right.$ $18,100 \%)$; HRMS $\left(\mathrm{ES}^{+}\right): \mathrm{MNH}_{4}^{+}$, 594.2887. $\mathrm{C}_{34} \mathrm{H}_{44} \mathrm{O}_{6} \mathrm{NS}$ requires 594.2884.

4.2.12 Cyclohex-2-en-1-one-3-carbaldehyde (33). ${ }^{17} \quad 4 \AA$ Molecular sieves (450 mg), NMO (370 mg, $3.12 \mathrm{mmol}$ ) and TPAP $(50 \mathrm{mg}, \quad 0.14 \mathrm{mmol})$ were added to 3methylenecyclohexanol $\quad \mathbf{3 2}^{16} \quad(100 \quad \mathrm{mg}, \quad 0.89 \quad \mathrm{mmol}) \quad$ in dichloromethane $(10 \mathrm{~mL})$ and the resulting mixture was stirred at rt for $84 \mathrm{~h}$ then filtered through a short pad of silica (DCM). After concentration under reduced pressure, chromatography of the residue (30:70 to 50:50 ether:light petroleum) gave the title compound $\mathbf{3 3}^{17}$ as a white solid (60 $\left.\mathrm{mg}, 0.48 \mathrm{mmol}, 54 \%\right), R_{f}=$ 0.42 (25:75 EtOAc:light petroleum); $\delta_{\mathrm{H}}\left(400 \mathrm{MHz}, \mathrm{CDCl}_{3}\right) 9.79$ $(1 \mathrm{H}, \mathrm{s}, \mathrm{CHO}), 6.56(1 \mathrm{H}, \mathrm{t}, J 1.7,2-\mathrm{H}), 2.53-2.57\left(2 \mathrm{H}, \mathrm{m}, 4-\mathrm{H}_{2}\right)$, $2.50\left(2 \mathrm{H}, \mathrm{m}, 6-\mathrm{H}_{2}\right)$ and $2.08\left(2 \mathrm{H}\right.$, quintet, $\left.J 6.5,5-\mathrm{H}_{2}\right) ; \delta_{\mathrm{C}}(125$ $\left.\mathrm{MHz}, \mathrm{CDCl}_{3}\right) 200.5,194.5,154.5,139.5,38.6,21.8$ and 21.5; $m / z\left(\mathrm{EI}^{+}\right) 124\left(\mathrm{M}^{+}, 100 \%\right)$.

The same procedure with reaction times as indicated in the text gave mixtures of products as outlined in Scheme 7; 37a $(16 \%) ; \delta_{\mathrm{H}}\left(400 \mathrm{MHz}, \mathrm{CDCl}_{3}\right) 9.81(1 \mathrm{H}, \mathrm{d}, J 7.1,5-\mathrm{H}), 6.85(1 \mathrm{H}$, $\mathrm{d}, J 16.6,3-\mathrm{H}), 6.76(1 \mathrm{H}, \mathrm{dd}, J 16.6,7.1,4-\mathrm{H})$ and $2.4(3 \mathrm{H}, \mathrm{s}, 1-$ $\left.\mathrm{H}_{3}\right) ; 37 \mathbf{b}(38 \%) ; \delta_{\mathrm{H}}\left(400 \mathrm{MHz}, \mathrm{CDCl}_{3}\right) 9.78(1 \mathrm{H}, \mathrm{d}, J 7.3,6-\mathrm{H})$, $6.99(1 \mathrm{H}, \mathrm{d}, J 16.1,4-\mathrm{H}), 6.82(1 \mathrm{H}, \mathrm{dd}, J 16.1,7.3,5-\mathrm{H}), 2.95$ $(1 \mathrm{H}$, sept, $J 6.8,2-\mathrm{H})$ and $1.12\left(6 \mathrm{H}, \mathrm{d}, J 6.8,1-\mathrm{H}_{3}, 2-\mathrm{CH}_{3}\right) ; 37 \mathrm{c}$ $(28 \mathrm{mg}, 0.17 \mathrm{mmol}, 26 \%)$ as a white solid, $R_{f}=0.32(30: 70$ ether:light petroleum); $v_{\max } / \mathrm{cm}^{-1} 2927,2854,1705,1692,1449$, $1375,1061,977,734,701,684,653$ and $617 ; \delta_{\mathrm{H}}(400 \mathrm{MHz}$, $\left.\mathrm{CDCl}_{3}\right) 9.79(1 \mathrm{H}, \mathrm{d}, J 7.3,4-\mathrm{H}), 6.99(1 \mathrm{H}, \mathrm{d}, J 15.9,2-\mathrm{H}), 6.83$ $(1 \mathrm{H}, \mathrm{dd}, J 15.9,7.6,3-\mathrm{H}), 2.69\left(1 \mathrm{H}, \mathrm{tt}, J 10.9,3.3,1^{\prime}-\mathrm{H}\right)$ and $1.2-$ $1.9(10 \mathrm{H}, \mathrm{m}) ; \mathrm{m} / z\left(\mathrm{EI}^{+}\right) 166\left(\mathrm{M}^{+}, 100 \%\right)$.

4.2 .13

(2RS, 10SR, 11SR, 12RS, 14RS, 3E, 7E)-10Benzenesulfonyl-2-benzyloxymethoxy-15-hydroxymethyl4,8,11,12-tetramethylbicyclo[9.3.1]pentadeca-1(15),3,7-trien-14ol (41). Di-isobutylaluminium hydride $(54 \mu \mathrm{L}, 0.054 \mathrm{mmol})$ was added to the keto-aldehyde $29(9 \mathrm{mg}, 0.0156 \mathrm{mmol})$ in DCM $(0.3$ $\mathrm{mL}$ ) at $-78{ }^{\circ} \mathrm{C}$ and the solution stirred at $-78{ }^{\circ} \mathrm{C}$ for $1 \mathrm{~h}$. Methanol was added and the mixture stirred at at $-78^{\circ} \mathrm{C}$ for 10 min then allowed to warm to rt. Aqueous Rochelle's salt ( $5 \%, 0.5$ $\mathrm{mL})$ and EtOAc $(0.5 \mathrm{~mL})$ were added and the mixture was stirred for $20 \mathrm{~min}$ then diluted with water $(1 \mathrm{~mL})$. The aqueous phase was extracted with EtOAc $(4 \times 2 \mathrm{~mL})$ and the organic extracts were washed with brine $(5 \mathrm{~mL})$, dried $\left(\mathrm{Na}_{2} \mathrm{SO}_{4}\right)$ and concentrated under reduced pressure. Chromatography of the residue (30:70 to 80:20 ether:light petroleum) gave the title compound $\mathbf{4 1}$ as a viscous oil ( $6 \mathrm{mg}, 66 \%), R_{f}=0.48$ (80:20 ether:light petroleum); $v_{\max } / \mathrm{cm}^{-1} 3500,2916,2848,1446,1386,1295,1146,1083,1023$, 909 and $727 ; \delta_{\mathrm{H}}\left(500 \mathrm{MHz}, \mathrm{CDCl}_{3}\right) 7.80-7.82(2 \mathrm{H}, \mathrm{m}, \mathrm{ArH}), 7.55$ $(1 \mathrm{H}, \mathrm{m}, \mathrm{ArH}), 7.45-7.49$ (2H, m, ArH $), 7.24-7.31$ (5H, m, ArH), $5.53(1 \mathrm{H}, \mathrm{dd}, J 8.5,0.6,3-\mathrm{H}), 5.10(1 \mathrm{H}, \mathrm{d}, J 8.5,2-\mathrm{H}), 4.73(1 \mathrm{H}$, $\mathrm{m}, 7-\mathrm{H}), 4.71$ and 4.67 (each $1 \mathrm{H}, \mathrm{d}, J 6.9, \mathrm{OHCHO}), 4.67(1 \mathrm{H}$, $\mathrm{m}, 15-\mathrm{CH}), 4.59$ and 4.48 (each $1 \mathrm{H}, \mathrm{d}, J 12.0, \mathrm{PhHCH}), 4.09$ $(1 \mathrm{H}, \mathrm{m}, 14-\mathrm{H}), 3.93(1 \mathrm{H}, \mathrm{t}, J 12.0, \mathrm{OH}) 3.63(1 \mathrm{H}, \mathrm{d}, J 6.6,10-\mathrm{H})$, $3.45\left(1 \mathrm{H}, \mathrm{dd}, J 11.3,1.6,15-\mathrm{CH}^{\prime}\right), 3.19(1 \mathrm{H}, \mathrm{m}, 12-\mathrm{H}), 2.44(1 \mathrm{H}$, d, $J 17.0,9-\mathrm{H}), 2.14\left(1 \mathrm{H}, \mathrm{dd}, J 17.0,7.9,9-\mathrm{H}^{\prime}\right), 2.09(1 \mathrm{H}, \mathrm{m}, 6-$ $\mathrm{H}), 1.93-2.04\left(4 \mathrm{H}, \mathrm{m}, 5-\mathrm{H}_{2}, 13-\mathrm{H}_{2}\right), 1.82\left(1 \mathrm{H}, \mathrm{m}, 6-\mathrm{H}^{\prime}\right), 1.58(3 \mathrm{H}$, $\left.\mathrm{s}, 8-\mathrm{CH}_{3}\right), 1.49\left(3 \mathrm{H}, \mathrm{s}, 4-\mathrm{CH}_{3}\right), 1.20(1 \mathrm{H}, \mathrm{m}, 14-\mathrm{OH}), 0.92(1 \mathrm{H}, \mathrm{d}$, $\left.J 6.9,12-\mathrm{CH}_{3}\right)$ and $0.66\left(3 \mathrm{H}, \mathrm{s}, 11-\mathrm{CH}_{3}\right) ; \delta_{\mathrm{C}}\left(125 \mathrm{MHz}, \mathrm{CDCl}_{3}\right)$, $142.5,141.9,140.3,137.8,137.6,133.5,131.7,129.2,128.8$, 128.6, 127.9, 127.8, 125.3(2), 92.4, 72.9, 69.9, 68.1, 66.0, 60.4, $45.9,39.1,37.0,36.6,26.2,19.2,16.2,15.9$ and $13.8 ; \mathrm{m} / z\left(\mathrm{ES}^{+}\right)$ $603.0\left(\mathrm{M}^{+}+23,100 \%\right) ;$ HRMS $\left(\mathrm{ES}^{+}\right): \mathrm{MNa}^{+}, 603.2760$. $\mathrm{C}_{34} \mathrm{H}_{44} \mathrm{O}_{6} \mathrm{SNa}$ requires 603.2751.

4.2.14 (4SR, 5RS, 7RS, 14SR, 15RS, 10E)-7,11,14,15Tetramethyl-3,6-bis-oxatetracyclo[12.4. $\left.0^{4,18} \cdot 0^{5,7}\right]$ octadeca1(18),10-diene-2,17-dione (42). Following the procedure outlined for the synthesis of the keto-aldehyde 29, the epoxydiol 15 (10 $\mathrm{mg}, 0.031 \mathrm{mmol}), 4 \AA$ molecular sieves $(8 \mathrm{mg})$, TPAP $(2 \mathrm{mg}$, $0.05 \mathrm{mmol})$ and NMO (18 mg, $0.16 \mathrm{mmol})$ in DCM $(0.8 \mathrm{~mL})$, after chromatography (40:60 ether:light petroleum), gave the title compound 42 as a white viscous oil ( $4 \mathrm{mg}, 48 \%), R_{f}=0.79$ (50:50 ether:light petroleum); $v_{\max } / \mathrm{cm}^{-1} 2918,2850,1766,1694$, $1455,1392,1262,1158,1047,912,870,792$ and $731 ; \delta_{\mathrm{H}}(500$ $\left.\mathrm{MHz} \mathrm{CDCl}_{3}\right) 4.94(1 \mathrm{H}, \mathrm{d}, J 6.6,4-\mathrm{H}), 4.85(1 \mathrm{H}, \mathrm{m}, 10-\mathrm{H}), 2.69$ (1H, ddd, $J 15.8,13.6,2.5,12-\mathrm{H}), 2.61$ (1H, ddq, $J 18.9,13.2$, $6.9,15-\mathrm{H}), 2.50(1 \mathrm{H}, \mathrm{d}, J 6.6,5-\mathrm{H}), 2.33-2.40\left(2 \mathrm{H}, \mathrm{m}, 16-\mathrm{H}_{2}\right)$, $2.29\left(1 \mathrm{H}, \mathrm{m}, 12-\mathrm{H}^{\prime}\right), 1.90(1 \mathrm{H}, \mathrm{m}, 13-\mathrm{H}), 1.89(1 \mathrm{H}, \mathrm{ddd}, J 15.8$, $5.0,2.5,8-\mathrm{H}), 1.77$ and 1.67 (each $1 \mathrm{H}, \mathrm{m}, 9-\mathrm{H}), 1.54(1 \mathrm{H}, \mathrm{dd}, J$ 5.3, 2.2, 13- $\left.\mathrm{H}^{\prime}\right), 1.48\left(4 \mathrm{H}, \mathrm{m}, 8-\mathrm{H}^{\prime}, 11-\mathrm{CH}_{3}\right), 1.33\left(1 \mathrm{H}, \mathrm{s}, 7-\mathrm{CH}_{3}\right)$, $1.16\left(1 \mathrm{H}, \mathrm{s}, 14-\mathrm{CH}_{3}\right)$ and $0.97\left(1 \mathrm{H}, \mathrm{d}, J 6.9,15-\mathrm{CH}_{3}\right) ; \mathrm{m} / z\left(\mathrm{ES}^{+}\right)$ $353.2\left(\mathrm{M}^{+}+23,100 \%\right)$; HRMS $\left(\mathrm{ES}^{+}\right): \mathrm{MH}^{+}, 331.1917 . \mathrm{C}_{20} \mathrm{H}_{27} \mathrm{O}_{4}$ requires 331.1904 .

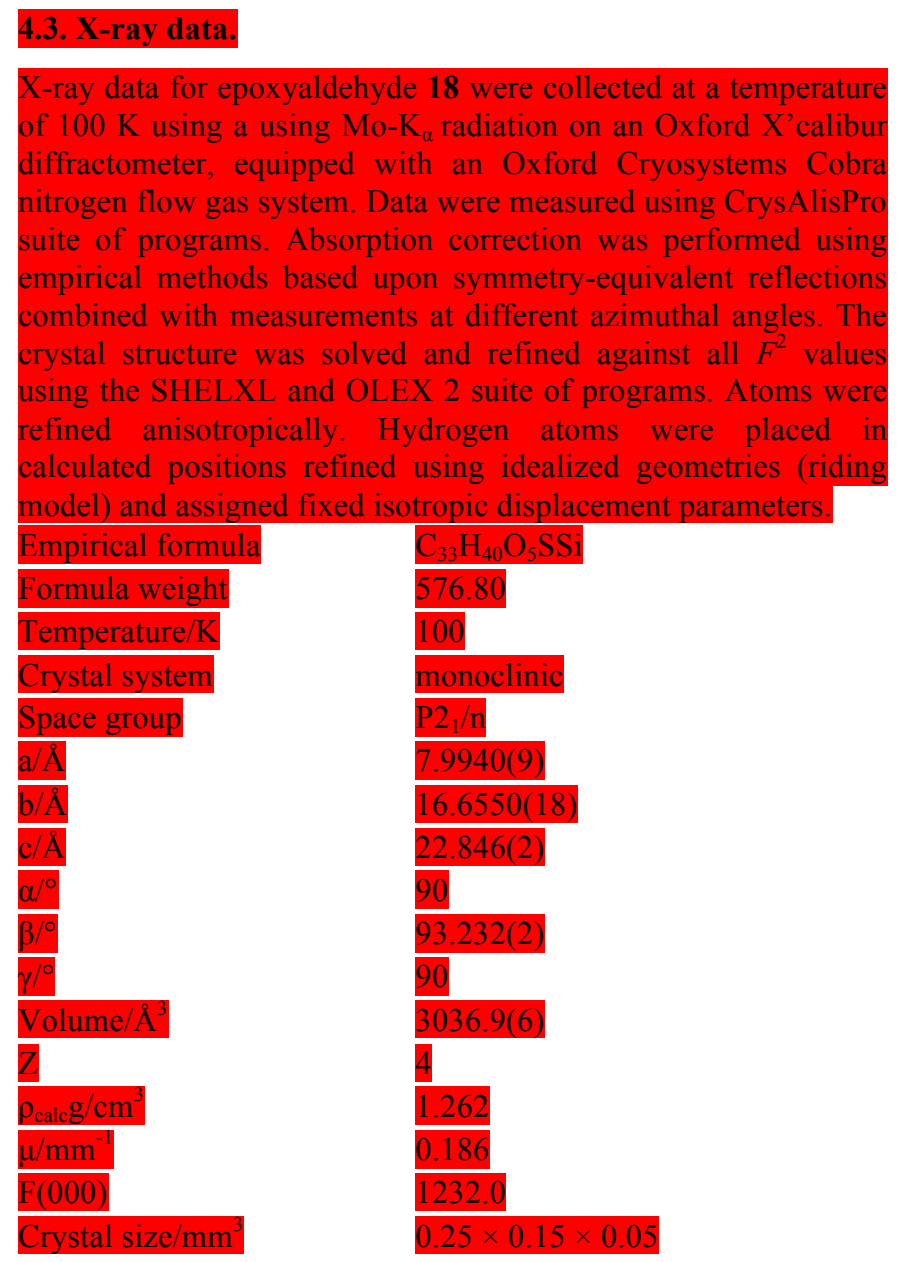



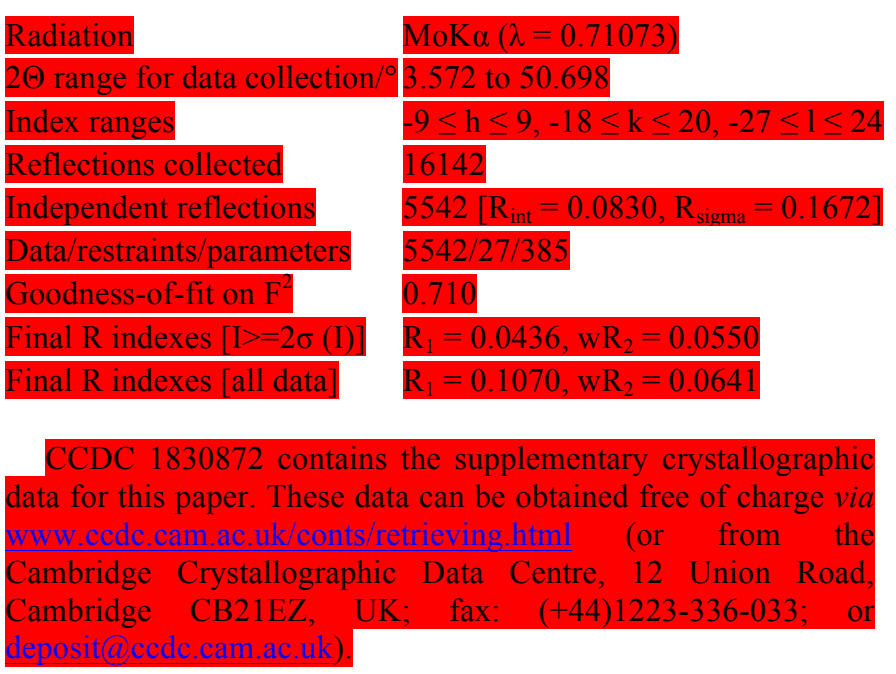

\section{Acknowledgments}

We thank the EPSRC for a studentship (to T. J. B.) and Eleanor Renwick for the studies of 3-methylenecyclohexanol 32 and the homoallylic alcohols 34 .

\section{References and notes}

1. (a) Sugano, M.; Sato, A.; Iijima, Y.; Oshima, T.; Furuya, K.; Kuwano, H.; Hata, T.; Hanzawa, H. J. Am. Chem. Soc. 1991, 113, 5463; (b) Sugano, M.; Sato, A.; Iijima, Y.; Furuya, K.; Kuwano, H.; Hata, T. J. Antibiot. 1995, 48, 1188.

2. For reviews of the chemistry of phomactins see: (a) Ciesielski, J.; Frontier, A. J. Org. Prep. Proc. Int. 2014, 46, 214; (b) Goldring, W. P. D.; Pattenden, G. Acc. Chem. Res. 2006, 39, 354.

3. For representative approaches see: (a) Ryu, K.; Cho, Y.-S.; Jung, S.-I.; Cho, C.-G. Org. Lett. 2006, 8, 3343; (b) Teng, D.; Wang, B.; Augatis, A. J.; Totah, N. I. Tetrahedron Lett. 2007, 48, 4605; (c) Huang, J.; Wang, H.; Wu, C.; Wulff, W. D. Org. Lett. 2007, 9 , 2799; (d) Goldring, W. P. D.; Alexander, S. P. H.; Kendall, D. A.; Pattenden, G. Bioorg. Med. Chem. Lett. 2005, 15, 3263; (e) You, L.-F.; Hsung, R. P.; Bedermann, A. A.; Kurdyumov, A. V.; Tan, Y.; Buchanan, G. S.; Cole, K. P. Adv. Synth. Cat. 2008, 350, 2885; (f) Schwartz, K. D.; White, J. D. Org. Lett. 2011, 13, 248; (g) Huang, S.; Du, G.; Lee, C.-S. J. Org. Chem. 2011, 76, 6534; (h) Buchanan, G. S.; Cole, K. P.; Li, G.; Tang, Y.; You, L.-F.; Hsung, R. P. Tetrahedron 2011, 67, 10105; (i) Ciesielski, J.; Cariou, K.; Frontier, A. J. Org. Lett. 2012, 14, 4082; (j) Ciesielski, J.; Gandon, V.; Frontier, A. J. J. Org. Chem. 2013, 78, 9541.
4. For total syntheses: (a) Miyaoka, H.; Saka, Y.; Miura, S.;

Yamada, Y. Tetrahedron Lett. 1996, 37, 7107; (b) Goldring, W. P. D.; Pattenden, G. Chem. Commun. 2002, 1736; (c) Diaper, C. M.; Goldring, W. P. D.; Pattenden, G. Org. Biomol. Chem. 2003, 1 , 3949; (d) Mohr, P. J.; Halcomb, R. L. J. Am. Chem. Soc. 2003, 125, 1712. (e) Goldring, W. P. D.; Pattenden, G. Org. Biomol. Chem. 2004, 2, 466; (f) Huang, J.; Wu, C.; Wulff, W. D. J. Am. Chem. Soc. 2007, 129, 13366; (g) Tang, Y.; Cole, K. P.; Buchanan, G. S.; Li, G,; Hsung, R. P. Org. Lett. 2009, 11, 1591; (h) Buchanan, G. S.; Cole, K. P.; Tang, Y.; Hsung, R. P. J. Org. Chem. 2011, 76, 7027.

5. Blackburn, T. J.; Kilner, M. J.; Thomas, E. J. Tetrahedron 2015, 71,7293 .

6. For earlier studies see: (a) McGowan, G.; Thomas, E. J. Org. Biol. Chem. 2009, 7, 2576; (b) Shapland, P. D. P.; Thomas, E. J. Tetrahedron 2009, 65, 4201.

7. Part of this work was initially reported in this communication: Blackburn, T. J.; Helliwell, M.; Kilner, M. J.; Lee, A. T. L.; Thomas, E. J. Tetrahedron Lett. 2009, 50, 3550.

8. For a discussion of the stereoselectivity of epoxidation of 2hydroxybicyclo[9.3.1]pentadeca-3,7-dienes, see reference (2a).

9. For directed epoxidation of homoallylic alcohols see: Mihelich, E. D.; Daniels. K.; Eickhoff, D. J. J. Am. Chem. Soc. 1981, 103, 7690.

10. Adam, W.; Wirth, T. Acc. Chem. Res. 1999, 32, 703.

11. (a) Torres, G.; Torres, W.; Prieto, J. A. Tetrahedron 2004, 60, 10245; (b) Perreux, L.; Loupy, A. Tetrahedron 2001, 57, 9199.

12. Parikh, J. R.; Doering, W. v. E. J. Am. Chem. Soc. 1967, 89, 5505.

13. (a) Cole, K. P.; Hsung, R. P. Chem. Commun. 2005, 5784; (b) Wood, J. L.; Graeber, J. K.; Njardarson, J. T. Tetrahedron 2003, 59,8855 .

14. (a) Ley, S. V.; Norman, J.; Griffith, W. P.; Marsden, S. P. Synthesis 1994, 639; (b) Griffith, W. P.; Ley, S. V.; Whitcombe, G. P.; White, A. D. J. Chem. Soc., Chem. Commun. 1987, 1625.

15. (a) Miranda Moreno, M. J. S.; Sá e Melo, M. L.; Campos Neves, A. S. Tetrahedron Lett. 1991, 32, 3201; (b) Acosta, C. K.; Rao, P. N.; Kim, H. K. Steroids, 1993, 58, 205.

16. Pulido, F. J.; Barbero, A.; Castreño, P. Eur. J. Org. Chem. 2010, 1307.

17. Baillargeon, V. P.; Stille, J. K. J. Am. Chem. Soc. 1986, 108, 452.

18. Chandler, W. D.; Wang, Z.; Lee, D. G. Canad. J. Chem. 2005, 83, 1212.

19. The configuration of the diol $\mathbf{4 1}$ was subsequently confirmed by an X-ray structure determination of a later intermediate; see ref 7 .

20. Dias, L. C.; Ferreira, A. A.; Diaz, G. Synlett 2002, 11, 1845.

21. Burnell, E. S.; Irshad, A.-R.; Raftery, J.; Thomas, E. J. Tetrahedron Lett. 2015, 56, 3255.

\section{Supplementary information}

Copies of ${ }^{1} \mathrm{H}$ and ${ }^{13} \mathrm{C}$ NMR spectra have been deposited

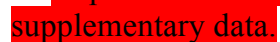

